\title{
Performance evaluation of HVOF deposited cermet coatings under dry and slurry erosion
}

\author{
Tom Peat ${ }^{a}$, Alexander Galloway ${ }^{a}$, Athanasios Toumpis ${ }^{a}$, David Harvey ${ }^{b}$, Wei-Hua Yang ${ }^{c}$ \\ aDepartment of Mechanical \& Aerospace Engineering, University of Strathclyde, James Weir \\ Building, 75 Montrose Street, Glasgow G1 1XJ, United Kingdom \\ ${ }^{\text {b}}$ TWI, Granta Park, Cambridge, CB21 6AL, United Kingdom \\ 'Beijing Aeronautical Manufacturing Technology Research Institute (BAMTRI), Baliqiao Qiao, \\ Chaoyang District, Beijing, China
}

\section{Abstract}

The present work reports on the examination of three High Velocity Oxy Fuel deposited coatings, Tungsten Carbide, Chromium Carbide and Aluminium Oxide, under slurry erosion and dry erosion conditions. The density and hardness of coatings produced in this manner are typically superior to other thermal spray processes, and are therefore suitable for use in corrosive and highly erosive environments. The primary aim of this investigation was to establish the total mass and volume loss from each coating under dry and slurry erosion testing conditions and compare the level of material loss following the respective testing regimes. The scope of the study incorporated the application of cathodic protection to prohibit the effects of corrosion in the case of slurry erosion testing. This approach ensured that any damage to the surface could be attributed to pure erosion, and as such, be assessed against the dry erosion test data. Subsequent examination of the resulting wear scars facilitated assessment of the level of damage caused by the impinging slurry. Results revealed variation in the level of degradation experienced by each coating type under the respective test conditions. Under both dry erosion and slurry erosion, Tungsten Carbide with a Cobalt binder 
proved an effective protective coating by exhibiting a reduction in material loss over other assessed coatings.

\section{Keywords}

Thermal spray coatings; Slurry erosion; Dry erosion; Wear; HVOF; Cermet 


\section{Introduction}

The deleterious effects of erosion and corrosion are widely observed within flow handling components. These can lead to increased downtime and in severe cases, the complete failure of a part or system [1-3]. This can have serious consequences in terms of operator safety and widespread environmental impact. The application of hard surface coatings is one technique developed to reduce the damaging effects of erosive particulates and extend the service life of components exposed to erosive environments [4]. High Velocity Oxy Fuel (HVOF) is one such technology and is used to deposit a variety of wear resistant coatings onto numerous substrate materials. Powder particles are accelerated to high velocities through a nozzle while simultaneously undergoing a state change from solid to molten or semi-molten, as a result of considerable heat input [5]. The high kinetic energy of particles as they impact the surface causes significant splat deformation [6], consequently producing a dense coating layer that is resistant to wear and corrosion [7-12].

There have been numerous studies on the erosion performance of HVOF coatings, most notably Tungsten carbide (WC) and Chromium carbide ( $\mathrm{CrC}$ ) based cermets [9,13-18]. In a study utilising pot-type slurry erosion, Goyal et al. [15] reported on the wear modes of HVOF sprayed WC$\mathrm{CoCr}$ and $\mathrm{Al}_{2} \mathrm{O}_{3}$ based coatings. The investigation focused solely on the effects of erosion and incorporated microstructural examination, calculation of volume loss and wear scar analysis to highlight the various wear mechanisms acting on the two coatings. The study [15] demonstrated a correlation between increased coating hardness and reduced volume loss, with Goyal et al. also attributing the increased volume loss of $\mathrm{Al}_{2} \mathrm{O}_{3}$ to its high melting point and the resulting presence of large, unmelted particles within the coating. Similarly, Ramesh et al. [14] carried out research on the erosion behaviour of HVOF sprayed WC based coatings on SA210 grade steel substrate. In this investigation [14] an erosive environment was achieved using dry silica sand that impinged onto the specimen surface at high velocities. Specifically, the study examined the impact of spraying parameters on the erosion resistance of the surface coating as well as characterising the wear 
damage on the specimen surface. Their results reported that the WC coatings suffer a higher rate of volume loss when compared with uncoated steel [14]. This is an unexpected result given the existing studies on HVOF coatings $[7,9,13]$ and was attributed, by Ramesh et al, to the increased hardness ratio between the silica erodent and the substrate steel. It was concluded that silica particles could have been embedded in the surface thereby shielding the substrate from impinging particles.

Despite both investigations $[14,15]$ seeking to evaluate the erosion performance of hard cermet coatings, there is little published research contrasting the two test regimes, slurry and dry erosion, on analogous surfaces. One such investigation by Thakur and Arora [19] examined the erosion of WC coatings under pot-type slurry impingement and dry jet erosion. The investigation [19] concluded that cermet coatings were highly erosion resistant when compared with the uncoated substrate and that dry jet erosion brought about substantially greater erosion rates over slurry erosion. This was attributed to all impinging particles striking the specimen at $90^{\circ}$, and to increased particle velocity as compared with pot-type slurry erosion. Despite highlighting this outcome, the impact angle between the two test regimes was not consistent [19]. Many researchers have shown the impingement angle to be directly linked to the recorded material loss [20-22], and as such, outcomes from this study [19] could be further refined by maintaining a consistent impact angle between the two testing methods. It would also be informative to evaluate the performance of additional HVOF coatings under analogous test conditions to establish if they demonstrate a similar response.

The present study provides novel insight on the comparative performance of HVOF deposited Tungsten carbide (WC-CoCr), Chromium carbide $\left(\mathrm{Cr}_{3} \mathrm{C}_{2}-\mathrm{NiCr}\right)$ and Aluminium oxide $\left(\mathrm{Al}_{2} \mathrm{O}_{3}\right)$ based coatings under slurry liquid impingement and dry jet erosion at a shallow angle of attack $\left(20^{\circ}\right)$. Through the use of slurry liquid impingement and dry jet erosion apparatus, the results established the material loss of each coating under both testing regimes and allowed conclusions to be drawn concerning the effect of testing conditions on the respective erosion performance of each coating material. The mass loss attributed to pure erosion under slurry impingement testing was 
isolated through applied cathodic protection, thereby preventing any electrochemical reaction between the slurry and the specimen surface. Micro-hardness examination along with metallographic analysis facilitated evaluation of coating properties and assessment of damage within the impact region. This body of research seeks to develop an enhanced understanding of the erosion performance of HVOF deposited WC-CoCr, $\mathrm{Cr}_{3} \mathrm{C}_{2}-\mathrm{NiCr}$ and $\mathrm{Al}_{2} \mathrm{O}_{3}$ coatings. Two testing regimes commonly used for erosion assessment were employed to determine whether dry jet erosion provides an accurate representation of the wear mechanisms within flowing conditions.

\section{Experimental methods}

\subsection{Materials}

Table 1 details the specific composition of WC-CoCr, $\mathrm{Cr}_{3} \mathrm{C}_{2}-\mathrm{NiCr}$ and $\mathrm{Al}_{2} \mathrm{O}_{3}$ feed powders. Each material was deposited on S355 steel substrate, (EN:10025), via HVOF spraying. Prior to spraying, the substrate plates were grit blasted with alumina particles and cleaned with methylated spirit. The specific spray parameters used for each coating can be found in Table 2 . Coatings were evaluated in the as-deposited condition, with surface peaks removed using 500 grit SiC paper.

Table 1

Powder properties [23-25]

\begin{tabular}{llll}
\hline $\begin{array}{l}\text { Coating } \\
\text { Material }\end{array}$ & Powder I.D. & Composition (wt.\%) & $\begin{array}{l}\text { Size Distribution } \\
(\mu \mathrm{m})\end{array}$ \\
\hline WC-CoCr & Woka 3652 & $80.6 \mathrm{~W}-10 \mathrm{Co}-4 \mathrm{Cr}-5.2 \mathrm{C}-0.2 \mathrm{Fe}$ & $-45+15$ \\
$\mathrm{Cr}_{3} \mathrm{C}_{2}-\mathrm{NiCr}$ & Woka 7202 & $69.9 \mathrm{Cr}-20 \mathrm{Ni}-9.6 \mathrm{C}-0.5 \mathrm{Fe}$ & $-45+15$ \\
$\mathrm{Al}_{2} \mathrm{O}_{3}$ & $\mathrm{Al}-1110-\mathrm{HP}$ & $100 \mathrm{Al}_{2} \mathrm{O}_{3}$ & $-22+5$ \\
\hline
\end{tabular}

Table 2

HVOF spray parameters

\begin{tabular}{llll}
\hline Deposition Parameter & WC-CoCr & $\mathrm{Cr}_{3} \mathrm{C}_{2}-\mathrm{NiCr}$ & $\mathrm{Al}_{2} \mathrm{O}_{3}$ \\
\hline Spray Gun & $\mathrm{DJ}-2600$ & $\mathrm{Tafa}$ JP5000 & UTP Top Gun \\
Standoff Distance $(\mathrm{mm})$ & 229 & 355 & 178 \\
Spray Angle $\left({ }^{\circ}\right)$ & 90 & 90 & 90 \\
Vertical Traverse Speed $(\mathrm{mm} / \mathrm{s})$ & 1.8 & 1.8 & 3 \\
Horizontal Traverse Speed $(\mathrm{mm} / \mathrm{s})$ & 1.13 & 1.33 & 1.13 \\
\hline
\end{tabular}




\begin{tabular}{llll}
\hline No. of Passes & 40 & 74 & 70 \\
Fuel flow rate $(\mathrm{I} / \mathrm{min})$ & 681.5 & 0.455 & 732 \\
Oxygen flow rate $(\mathrm{l} / \mathrm{min})$ & 229.8 & 860 & 262 \\
Carrier gas flow rate $(\mathrm{I} / \mathrm{min})$ & 369.4 & 9.911 & 23.6 \\
\hline
\end{tabular}

\subsection{Coating characterisation}

Coating microstructure was characterised by light optical and scanning electron microscopy (SEM), facilitated by an Olympus G51X series light optical microscope and a Hitachi S-3000N SEM. Energy Dispersive Spectroscopy (EDS) provided the chemical analysis of the coatings through spot analysis of specific regions within the coating layer. Specimens were cross-sectioned and prepared for microstructural evaluation using standard metallographic preparation techniques. A Mitutoyo MVK-G1 micro-hardness indenter with applied load of $200 \mathrm{gf}$ provided hardness values for the deposited coatings. A Mercury Intrusion Porosimeter (Quantachrome Poremaster 60) facilitated the assessment of coating density. In order to isolate porosity in the coating layer, a precision cutting wheel (Accutom - 5) was employed to remove the bulk substrate material, with subsequent acid bath to eliminate any remaining traces of S355 steel. Optical porosity measurements recorded in accordance with ASTM E2109 - 01(2014) [26] validated the porosimetry results.

\subsection{Dry erosion testing}

A sand blasting gun with inverted particle feeder, shown as a schematic in Figure 1, was selected to carry out dry erosion testing. Comparable systems have been utilized in previous studies $[14,19,27,28]$

Erosion testing was carried out at room temperature using a method based on GE E50TF121 specification [29] on the three selected coatings. The test sample was mounted at $20^{\circ}$ to the jet stream at a standoff distance of $100 \mathrm{~mm}$. Alumina with an average particle size of $50 \mu \mathrm{m}$ was accelerated onto the surface at a feed rate of $5.3 \mathrm{~g} / \mathrm{s}$, with the test concluded when $300 \mathrm{~g}$ of alumina had been passed through the jet nozzle. Samples were weighed in the pre- and post-test conditions to attain the mass loss for each coating with associated volume loss. 


\subsection{Liquid impingement}

A closed loop jet impingement rig, shown as a schematic in Figure 2, was selected to facilitate the slurry erosion experiments as similar systems have been used in existing studies to determine the effects of erosion and corrosion within a flowing environment [22,30-32]. A closed loop system offers the ability to accurately control and alter the flow velocity, modify the impingement angle and manipulate the quantity of erosive particles within the slurry. These variables are known to influence the rate of mass loss [21,33]. The slurry used throughout the study comprised of a $3.5 \mathrm{wt} . \% \mathrm{NaCl}$ solution containing FS9 grade angular silica sand with an average particle size of $0.355 \mathrm{~mm}$. Test specimens were positioned directly beneath the nozzle, whilst fully immersed in the slurry solution. Pump 2 allowed removal of slurry, with the system subsequently flushed with fresh water to remove all trace particulates, thereby ensuring consistent sand concentration throughout all experimental trials. Table 3 details the experimental parameters for the liquid impingement tests.

All specimens were lightly abraded using 500 grit SiC paper, to produce a uniform surface finish and weighed using a mass balance to an accuracy of $0.1 \mathrm{mg}$. Specimens were weighed prior to, and following testing to determine the total mass loss. Three test replicates of each coating were measured to provide an average mass loss value. Volume loss was determined on the Alicona system through non-contact optical assessment of the wear scar region.

\section{Table 3}

Liquid Impingement Test Parameters

\begin{tabular}{llllll}
\hline $\begin{array}{l}\text { Flow Velocity } \\
(\mathrm{m} / \mathrm{s})\end{array}$ & $\begin{array}{l}\text { Sand Concentration } \\
(\mathrm{g} / \mathrm{l})\end{array}$ & $\begin{array}{l}\text { Standoff Distance } \\
(\mathrm{mm})\end{array}$ & $\begin{array}{l}\text { Impingement } \\
\text { Angle }\left({ }^{\circ}\right)\end{array}$ & $\begin{array}{l}\text { Test } \\
\text { Time }(\mathrm{hr})\end{array}$ & $\begin{array}{l}\text { Sample Diameter } \\
(\mathrm{mm})\end{array}$ \\
\hline 24 & 2.3 & 20 & 20 & 1 & 20 \\
\hline
\end{tabular}

\subsection{Electrochemical measurement}

To facilitate a direct comparison between dry erosion and slurry erosion, it was necessary to isolate the effects of pure erosion by preventing any corrosion occurring throughout the slurry 
erosion test. Cathodic protection was applied with the aim of preventing any electrochemical reaction between the material surface and the slurry, thereby allowing the calculation of the mass loss relating to pure erosion. A WaveNow Potentiostat in conjunction with Aftermath data acquisition software applied cathodic protection to the specimen surface. Platinum foil served as the auxiliary electrode with a Double Junction $\mathrm{Ag} / \mathrm{AgCl}$ electrode serving as the reference. A potential of $-1 \mathrm{~V}$ versus the $\mathrm{Ag} / \mathrm{AgCl}$ electrode was applied across the specimen which supressed the anodic reaction and prevented the occurrence of corrosion.

\subsection{Surface topography}

Surface analysis following slurry erosion was conducted to evaluate the level of damage to each coating material. An SEM allowed examination of the wear scar region, with scanning electron micrographs of the impinged surface captured to depict the various mechanisms causing material removal. Surface roughness for each coating type was measured using a Mitutoyo SV 2000 profilometer. An Alicona (Infinite Focus G4) non-contact optical surface characterisation system facilitated the assessment of the wear scar region and determined the volume loss within the wear scar in addition to calculating the wear scar depth.

\section{Results and discussion}

\subsection{Pre-test characterisation}

Prior to both liquid impingement and dry erosion testing, sectioned specimens of asdeposited WC-CoCr, $\mathrm{Cr}_{3} \mathrm{C}_{2}-\mathrm{NiCr}$ and $\mathrm{Al}_{2} \mathrm{O}_{3}$ coatings were examined to identify the various features within each of their respective microstructures.

\subsubsection{Microstructural analysis}

Table 4 details the coating thickness, porosity and average carbide/oxide size for each coating type, as well as the respective average hardness and surface roughness values. Results reveal WC-CoCr and $\mathrm{Cr}_{3} \mathrm{C}_{2}-\mathrm{NiCr}$ to have similar coating thickness, with the $\mathrm{Al}_{2} \mathrm{O}_{3}$ layer being approximately $130 \mu \mathrm{m}$ greater in depth. Measurement of mean carbide/oxide size recorded $\mathrm{Al}_{2} \mathrm{O}_{3}$ as 
having the largest average size, followed by $\mathrm{Cr}_{3} \mathrm{C}_{2}-\mathrm{NiCr}$ then WC-CoCr. There have been numerous studies examining the effect of carbide/oxide size on the wear performance of HVOF deposited coatings $[13,34,35]$, the outcomes of which demonstrate an increase in wear rate with increasing carbide/oxide size. Mercury intrusion porosimetry revealed WC-CoCr to possess noticeably greater density than that of $\mathrm{Cr}_{3} \mathrm{C}_{2}-\mathrm{NiCr}$ or $\mathrm{Al}_{2} \mathrm{O}_{3}$. This is likely a function of carbide size (Table 4) within the sprayed powder. As the powder is sprayed, the presence of large carbides limits the particle deformation upon contact with the substrate surface [36]. The deformation of particles is necessary for the coating to coalesce. Therefore, the deposition of particles containing larger carbides results in void spaces where the particles have failed to amalgamate with surrounding particles. A confirming trend has been observed in corresponding studies [36-38], with authors attributing the increased flattening of particles following impact to the presence of smaller carbides within the feedstock powder [36]. It should be noted that further optimisation of the spray parameters could reduce the level of porosity within each respective coating. For both $\mathrm{WC}-\mathrm{CoCr}$ and $\mathrm{Al}_{2} \mathrm{O}_{3}$, the porosity measurements obtained through ImageJ analysis validated values calculated using mercury intrusion porosimetry. The two measurement techniques however revealed contrasting values for the $\mathrm{Cr}_{3} \mathrm{C}_{2}-\mathrm{NiCr}$ specimen, with ImageJ indicating a coating 1.6 times more porous than that determined through porosimetry.

Table 4

Coating properties.

\begin{tabular}{llllllll}
\hline Coating & $\begin{array}{l}\text { Thickness } \\
(\mu \mathrm{m})\end{array}$ & Porosity (Vol.\%) & $\begin{array}{l}\text { Average } \\
\text { Carbide/Oxide } \\
\text { Size }(\mu \mathrm{m})\end{array}$ & $\begin{array}{l}\text { Average } \\
\text { Hardness } \\
(\mathrm{HV})\end{array}$ & $\begin{array}{l}\text { Density } \\
\left(\mathrm{g} / \mathrm{cm}^{3}\right)\end{array}$ & $\begin{array}{l}\text { Surface } \\
\text { Roughness, } \mathrm{R}_{\mathrm{a}} \\
(\mu \mathrm{m})\end{array}$ \\
\hline Uncoated & $\mathrm{N} / \mathrm{A}$ & $\mathrm{N} / \mathrm{A}$ & $\mathrm{N} / \mathrm{A}$ & $\mathrm{N} / \mathrm{A}$ & 200 & $\mathrm{~N} / \mathrm{A}$ & 0.172 \\
WC-CoCr & 163 & 0.240 & 0.2 & 1.07 & 1364 & 12.89 & 4.119 \\
$\mathrm{Cr}_{3} \mathrm{C}_{2}-\mathrm{NiCr}$ & 176 & 1.306 & 2.1 & 3.47 & 1006 & 6.30 & 1.855 \\
$\mathrm{Al}_{2} \mathrm{O}_{3}$ & 294 & 1.347 & 1.3 & 13.5 & 1164 & 2.54 & 1.063 \\
\hline
\end{tabular}


Any defects in the coating layer have significant detrimental impact on the erosion performance of the coating, as reported by existing studies $[30,39]$. In the case of WC-CoCr, light optical microscopy revealed a generally dense coating layer with no visible cracking following deposition. Despite this, small pores are visible and occur when sprayed particles fail to achieve sufficient temperature to deform and bond with the surrounding particles [40]. Within the interface region there exists evidence of inclusions that reduce the splat area contact [41] with the substrate leading to poorer adhesion of coatings [41]. In general, regions void of any inclusions or defects demonstrate a well mixed matrix of WC particles and CoCr binder. In some instances however, it is evident that WC particles coalesce to form large carbide rich regions, with softer Co also amalgamating into elongated Co regions.

SEM with EDS provided verification of features highlighted through light optical microscopy. Figure 5 depicts the various features and locations where EDS spot analysis was performed. Scanning of regions denoted as spectra 1 and 2 produced comparatively low deadtime, indicating that the areas scanned are void locations. Defect free regions present chemical compositions reflecting the composition of the sprayed particles (Table 1) .

Figure 6a presents a micrograph of the $\mathrm{Cr}_{3} \mathrm{C}_{2}-\mathrm{NiCr}$ coating. As with WC-CoCr, the coating layer is generally dense with minimal porosity. There is evidence of carbide pull-out which can be attributed to the metallographic preparation process [42].

Figure $6 \mathrm{~b}$ reveals small pores within the coating layer which tend to form along the interface between carbide and binder material [40]. As with WC-CoCr, the $\mathrm{CrC}$ and $\mathrm{Ni}-\mathrm{Cr}$ binder have on the whole, mixed well following the HVOF deposition, however regions of concentrated $\mathrm{Ni}-\mathrm{Cr}$ and $\mathrm{CrC}$ do exist within the coating matrix.

Figure $5 \mathrm{~b}$ highlights the various regions within the $\mathrm{Cr}_{3} \mathrm{C}_{2}-\mathrm{NiCr}$ specimen subjected to EDS analysis. Examination of locations 2, 5, 6 \& 7 (Table 5) revealed wt.\% in line with the composition of sprayed powder, with $\mathrm{Ni}$ and $\mathrm{Cr}$ being the dominant elements present. Spectra $3 \& 4$ were conducted on inclusions within the coating. EDS analysis recording high quantites (> $80 \mathrm{wt} . \%$ ) of 
Tungsten in this region. The almost neglible presence of Tungsten is a by-product of the matallographic preparation process. Spectrum 8 refers to a large particle within the $\mathrm{Cr}_{3} \mathrm{C}_{2}-\mathrm{NiCr}$ matrix. EDS reported significantly high levels of $\mathrm{Al}$ (> $40 \mathrm{wt} . \%)$ and Oxygen (> $50 \mathrm{wt} . \%)$, thereby indicating that the inclusion is an Alumina particle.

An optical micrograph of the $\mathrm{Al}_{2} \mathrm{O}_{3}$ coating is presented in Figure $7 \mathrm{a}$, with Figure $7 \mathrm{~b}$ depicting a scanning electron micrograph of the same region. As with $\mathrm{Cr}_{3} \mathrm{C}_{2}-\mathrm{NiCr}$ and WC-CoCr, the $\mathrm{Al}_{2} \mathrm{O}_{3}$ coating presented a dense structure showing limited signs of porosity or inclusions within the coating layer (Figure 7a). The micrograph, (Figure 7b) exhibits signs of limited porosity and corroberates the findings of the porosimetry (Table 4). The high particle temperature is sufficient to cause flattening [43] of the alumina particles. However, due to the oxide particles being larger than the carbides retained in the cermet powders [36-38], the porosity of the $\mathrm{Al}_{2} \mathrm{O}_{3}$ coating is greater than that of WC-CoCr and $\mathrm{Cr}_{3} \mathrm{C}_{2}-\mathrm{NiCr}$. Results of SEM analysis present consistent chemical composition throughout the coating. As expected quantities of Oxygen (53 wt.\%) and Aluminium (47 wt.\%) were detected, with any other trace elements being below $0.5 \mathrm{wt} . \%$.

\section{Table 5}

Recorded values from EDS scans of various regions within $\mathrm{Cr}_{3} \mathrm{C}_{2}-\mathrm{NiCr}$ coating.

\begin{tabular}{|c|c|c|c|c|c|c|c|c|}
\hline & \multicolumn{8}{|c|}{ Detected Element (wt.\%) } \\
\hline & 0 & $\mathrm{Al}$ & $\mathrm{Ti}$ & $\mathrm{Cr}$ & $\mathrm{Fe}$ & Co & $\mathrm{Ni}$ & W \\
\hline Spectrum 2 & 1.72 & & & 44.06 & 1.97 & & 52.24 & \\
\hline Spectrum 3 & 1.56 & & & 5.97 & 0.30 & 7.48 & 3.02 & 81.65 \\
\hline Spectrum 4 & 0.78 & & & 4.63 & & 0.91 & 2.11 & 91.58 \\
\hline Spectrum 5 & & & & 18.97 & 0.85 & & 78.56 & 1.62 \\
\hline Spectrum 6 & & & & 96.93 & 0.15 & & 1.16 & 1.77 \\
\hline Spectrum 7 & 1.70 & & & 78.56 & 4.73 & & 15.00 & \\
\hline Spectrum 8 & 51.63 & 47.16 & 0.73 & & 0.48 & & & \\
\hline
\end{tabular}

\subsubsection{Micro-hardness measurements}

Figure 8 illustrates the variation in micro-hardness between the three coatings with values recorded at intervals of $20 \mu \mathrm{m}$ through the coating thickness. WC-CoCr exhibited the highest overall average hardness at $1364 \mathrm{HV}$. This constitutes a substantial increase over the S355, found to have a 
hardness value of $200 \mathrm{HV}$. Light optical microscopy of hardness indents illustrates a direct relationship between coating density and indicated hardness, with the lowest hardness measurements obtained in close proximity to porosity, and the highest hardness obtained in a closely packed region. The average hardness values for $\mathrm{Cr}_{3} \mathrm{C}_{2}-\mathrm{NiCr}$ and $\mathrm{Al}_{2} \mathrm{O}_{3}$ coatings were $852 \mathrm{HV}$ and $1044 \mathrm{HV}$ respectively.

\subsection{Erosion testing}

\subsubsection{Dry erosion regime}

Variation in mass and volume loss values between the three coatings following dry erosion testing is presented in Figure 9.

Results show that WC-CoCr and $\mathrm{Cr}_{3} \mathrm{C}_{2}-\mathrm{NiCr}$ experience similar levels of mass loss, with $\mathrm{Al}_{2} \mathrm{O}_{3}$ exhibiting comparably low mass loss. When coating density (Table 4) is taken into consideration, the calculated volume loss produces a variation on this trend. The low density of $\mathrm{Al}_{2} \mathrm{O}_{3}$ and the comparatively high density of WC-CoCr result in both specimens yielding similar volume loss values, with $\mathrm{Cr}_{3} \mathrm{C}_{2}-\mathrm{NiCr}$ coated specimens experiencing around double the volume loss. Based on these findings and those outlined in Figure 8, it can be concluded that, under dry erosion testing, coatings possesing higher hardness perform favourably under impingement at $20^{\circ}$. This outcome is in agreement with existing studies on the erosion of materials at shallow angles of attack $[44,45]$.

\subsubsection{Slurry erosion regime}

Figure 10 demonstrates the influence of coating type on the total mass and volume loss following 1 hour of slurry erosion testing with applied CP. Results highlight the significant reduction in mass loss of the WC-CoCr coated specimen over $\mathrm{Cr}_{3} \mathrm{C}_{2}-\mathrm{NiCr}$ and $\mathrm{Al}_{2} \mathrm{O}_{3}$ coatings. Volumetric analysis reveals $\mathrm{Cr}_{3} \mathrm{C}_{2}-\mathrm{NiCr}$ and $\mathrm{Al}_{2} \mathrm{O}_{3}$ coated specimens to have exhibited comparable quantities of removed material. WC-CoCr again outperformed all other coatings through a significant reduction in overall volume loss. 


\subsubsection{Comparison of erosion data}

Direct comparison of volume loss under slurry and dry erosion (Figure 11) shows significantly increased levels of material loss under dry erosion conditions. This can be attributed to both the variation in impact velocity and the morphology of impinging particles, between the two testing regimes. Existing research has shown particle velocity under slurry conditions to be significantly reduced as a consequence of the squeeze film effects $[46,47]$. Squeeze film is the phenomenon whereby the slurry acts as a barrier between the impinging particles and the surface $[46,47]$. Energy is required to break this barrier, which in turn, decreases the particle impact velocity. As a result, the cumulative erosive damage is reduced. Conversely, the particle velocity under dry erosion will reflect the gas velocity emanating from the nozzle [48]. The variation in particle morphology also accounts for the increased volume loss under dry jet erosion with Levy et al. [49] demonstrating a rise in the erosion rate with increased erodent hardness. Numerous studies also report the influence of erosive particle material, size and shape on the recorded erosion rate $[27,49-51]$.

Volume loss with respect to coating hardness, for both test regimes, is displayed in Figure 12. Under dry erosion conditions, the $\mathrm{Al}_{2} \mathrm{O}_{3}$ coating suffers comparable volume loss with WC-CoCr. Conversely, slurry erosion conditions result in the $\mathrm{Al}_{2} \mathrm{O}_{3}$ specimen experiencing similar volume loss to the $\mathrm{Cr}_{3} \mathrm{C}_{2}-\mathrm{NiCr}$. Two significant observations can be identified from this data. The first is that the $\mathrm{Cr}_{3} \mathrm{C}_{2}-\mathrm{NiCr}$ coating has produced the greatest volume loss under both test regimes. Given that $\mathrm{Cr}_{3} \mathrm{C}_{2^{-}}$ $\mathrm{NiCr}$ posseses the lowest overall hardness of the three coatings, it can be argued that coating hardness is inversly proportional to volume loss at shallow angles of attack. This is in agreement with the work of several research groups $[14,21,44,45,52]$. The second observation concerns the variation in the volume loss between each coating type under the two test regimes. The data shows that WC$\mathrm{CoCr}$ and $\mathrm{Al}_{2} \mathrm{O}_{3}$ coatings behave differently under dry erosion and slurry erosion. Specifically, WC$\mathrm{CoCr}$ demonstrates a comparably high volume loss under dry erosion, with $\mathrm{Al}_{2} \mathrm{O}_{3}$ demonstrating increased volume loss under slurry erosion. Thus, for ceramic-based coatings, dry erosion testing does not necessarily reflect the erosion mechanisms and associated material losses that are 
encountered under slurry erosion. Therefore, dry erosion testing will not act as a suitable benchmark for the performance of coatings within a slurry based flowing environment.

\subsection{Impinged surface analysis}

\subsubsection{Macro examination of eroded surfaces}

The wear scar of each coating material and uncoated S355 was captured using an Alicona optical imaging system (Figure 13). Table 6 outlines the corresponding wear scar depth for each specimen following slurry erosion trials, measured using the Alicona system. Results reveal a significant variation in the typical wear scar produced. The uncoated specimen has developed the largest wear scar, with a maximum-recorded depth of $628.82 \mu \mathrm{m}$. The recorded scar depth for $\mathrm{Cr}_{3} \mathrm{C}_{2}{ }^{-}$ $\mathrm{NiCr}$ and for $\mathrm{Al}_{2} \mathrm{O}_{3}$ are similar. When compared with the as-deposited coating thickness (Table 4), this demonstrates that neither the $\mathrm{Cr}_{3} \mathrm{C}_{2}-\mathrm{NiCr}$ nor the $\mathrm{Al}_{2} \mathrm{O}_{3}$ coatings have been breached during the slurry erosion test. The measured scar depth for WC-CoCr had a maximum value of $50.84 \mu \mathrm{m}$. With an indicated coating thickness of $180 \mu \mathrm{m}$, (Table 4) the results verify that the coating layer has not been breached following the 1-hour slurry erosion test. The significant reduction in wear scar demonstrates WC-CoCr has provided superior erosion resistance over the other assessed coatings under impingement at $20^{\circ}$.

\section{Table 6}

Wear scar depth

\begin{tabular}{lllll}
\hline Specimen & Uncoated & WC-CoCr & $\mathrm{Cr}_{3} \mathrm{C}_{2}-\mathrm{NiCr}$ & $\mathrm{Al}_{2} \mathrm{O}_{3}$ \\
Scar Depth $(\mu \mathrm{m})$ & 628.82 & 50.84 & 137.05 & 136.28 \\
\hline
\end{tabular}

\subsubsection{Characterisation of eroded surfaces}

The specimens subjected to slurry erosion tests at $20^{\circ}$ were examined using SEM to facilitate further evaluation of the respective wear mechanisms operating within the impinged region on specific coating materials.

Figure 14a exhibits substantial cutting and lip formation within the impinged zone on the uncoated S355. This wear pattern is consistent with the erosion of ductile materials as noted by 
Finnie [53]. The mechanisms of material removal at shallow impact angles are noticeably different from attack at $90^{\circ}$ [22]. In the case of shallow angles of attack, the primary mechanisms causing material loss, as identified by previous research $[21,22]$ can be attributed to cutting and scoring of the ductile surface. Repeated impact leads to the formation of lips, as indicated in Figure 14a. Continued exposure to the high velocity jet results in the removal of these lips leading to extensive material loss of the uncoated S355 steel. Figure 14a highlights the directionality within the wear scar, with evidence of parallel scratch patterns and ploughing within the impinged region.

A scanning electron micrograph showing the wear scar of WC-CoCr is depicted in Figure 14b. When compared with Figure 14a, the image highlights that the mechanisms resulting in material removal are different for ductile and ceramic substrates. Specifically, the WC-CoCr micrograph (Figure 14b), reveals extensive carbide removal with noticeably less scoring and cutting. Evidence of scoring is visible, however is contained within the ductile Cobalt binder. This feature is to be expected given the comparably low hardness of Cobalt over WC. Repeated impact causes the breakdown of the binder, typically initiating at the carbide-binder interface [54]. The removal of Cobalt leads to a lack of binding material capable of retaining the carbides within the coating, eventually resulting in them being plucked from the surface by the impinging slurry. These observations align with the widely accepted breakdown mechanism of WC-CoCr based coatings under slurry erosion [55-58].

Figure $14 \mathrm{c}$ depicts the impinged region of the $\mathrm{Cr}_{3} \mathrm{C}_{2}-\mathrm{NiCr}$ coated specimen and highlights the existence of both ductile and brittle mechanisms of material removal. Specifically, the image exhibits the presence of cutting and ploughing marks, in addition to pull-out and micro-cracking. The existence of the observed features leads to the conclusion that the $\mathrm{Cr}_{3} \mathrm{C}_{2}-\mathrm{NiCr}$ demonstrates both brittle and ductile modes of material removal. A study by Hong et al. [59] reported a similar result following the cavitation silt-erosion of $\mathrm{Cr}_{3} \mathrm{C}_{2}-\mathrm{NiCr}$. Moreover, corresponding features were identified by Zavareh et al. [18] following tribological and electrochemical assesment of a $\mathrm{Cr}_{3} \mathrm{C}_{2}-\mathrm{NiCr}$ coating 
The impinged region of the $\mathrm{Al}_{2} \mathrm{O}_{3}$ coated specimen contains unique features not observed within the previously examined wear scars. The pure ceramic coating is highly brittle and possesses no ductile binder. As a consequence, erosion is dominated by micro-cracking and delamination of splats, (plastically deformed particles) [41], from the surface. Figure $14 \mathrm{~d}$ depicts some of these features within the impinged region. The lack of ductile binder results in the removal of the $\mathrm{Al}_{2} \mathrm{O}_{3}$ layer due to the low cohesive strength between deposited particles [60]. This leads to the removal of coating "flakes" from the surface. An extensive study by Yang et al. [60] recorded a corresponding outcome on $\mathrm{Al}_{2} \mathrm{O}_{3}$ coatings with varying levels of $\mathrm{Cr}_{2} \mathrm{O}_{3}$. The addition of $\mathrm{Cr}_{2} \mathrm{O}_{3}$ was shown to increase the cohesive strength of the coating layer thereby improving the erosion resistance [60].

\section{Conclusions}

This work documents the results of an experimental investigation into the erosion performance of HVOF deposited WC-CoCr, $\mathrm{Cr}_{3} \mathrm{C}_{2}-\mathrm{NiCr}$ and $\mathrm{Al}_{2} \mathrm{O}_{3}$ coatings under slurry erosion and dry jet erosion. The novelty of this study was furthered through the application of cathodic protection to eliminate the effects of corrosion under slurry erosion. Mass and volume loss for each coating material was established with the mechanisms causing coating degradation evaluated through examination of the resulting wear scars.

- Considering the specific densities of the three reinforcement particles, mass loss does not provide a suitable metric with which to assess the erosion performance of the HVOF coatings. Hence, the determination of volume loss is necessary for a comparative evaluation of dissimilar HVOF coatings.

- Volume loss under dry erosion was found to be more than 5 times greater than volume loss under slurry conditions, in the case of WC-CoCr coated specimens. Squeeze film effects, which reduce impinging particle impact velocity in the presence of a slurry erosion environment, and variation in erodent particle size and hardness, account for the recorded increase to volume loss under dry erosion conditions. 
- $\mathrm{Cr}_{3} \mathrm{C}_{2}-\mathrm{NiCr}$ produced the highest recorded volume loss out of all examined coatings, both in dry erosion and slurry erosion conditions. From this, it can be concluded that $\mathrm{Cr}_{3} \mathrm{C}_{2}-\mathrm{NiCr}$ is not the optimum choice of coating material to provide increased erosion resistance in flowing or dry erosive environments.

- WC-CoCr experienced a significant reduction in volume loss and wear scar depth over $\mathrm{Cr}_{3} \mathrm{C}_{2}-$ $\mathrm{NiCr}$ and $\mathrm{Al}_{2} \mathrm{O}_{3}$ at an impingement angle of $20^{\circ}$, under both dry jet and slurry erosion. Minimal volume loss and wear scar depth is attributed to high coating hardness and the ability of the Cobalt matrix to retain the hard carbide particles.

- WC-CoCr and $\mathrm{Al}_{2} \mathrm{O}_{3}$ coatings exhibited contrasting responses under slurry and dry erosion, with WC-CoCr demonstrating a comparably high mass loss and associated volume loss under dry erosion and $\mathrm{Al}_{2} \mathrm{O}_{3}$ exhibiting increased volume loss under slurry erosion. This suggests that, for the examined coatings, dry erosion does not necessarily reflect the erosion mechanisms encountered under slurry erosion; therefore, dry erosion is not suitable for evaluation of coatings under flowing conditions.

\section{References}

[1] J. Madadnia, J. Kusnan, Analysis of Severe Erosion in Industrial Centrifugal Slurry Pumps, in: Proc. ASME 2013 Fluids Eng. Div. Summer Meet., Nevada, 2013: pp. 1-7.

[2] C.I. Walker, P. Robbie, Comparison of some laboratory wear tests and field wear in slurry pumps, Wear. 302 (2013) 1026-1034.

[3] C.I. Walker, Slurry pump side-liner wear: Comparison of some laboratory and field results, Wear. 250-251 (2001) 81-87.

[4] K. Sugiyama, S. Nakahama, S. Hattori, K. Nakano, Slurry wear and cavitation erosion of thermal-sprayed cermets, Wear. 258 (2005) 768-775.

[5] L. Pawlowski, The Science and Engineering of Thermal Spray Coatings, 2008.

[6] M. Ivosevic, R.A. Cairncross, R. Knight, 3D predictions of thermally sprayed polymer splats: Modeling particle acceleration, heating and deformation on impact with a flat substrate, Int. J. Heat Mass Transf. 49 (2006) 3285-3297.

[7] G. Bolelli, L. Lusvarghi, M. Barletta, HVOF-sprayed WC-CoCr coatings on Al alloy: Effect of the coating thickness on the tribological properties, Wear. 267 (2009) 944-953.

[8] J.R. García, J.E. Fernández, J.M. Cuetos, F.G. Costales, Fatigue effect of WC coatings thermal sprayed by HVOF and laser treated, on medium carbon steel, Eng. Fail. Anal. 18 (2011) 17501760.

[9] S. Matthews, B. James, M. Hyland, The role of microstructure in the mechanism of high 
velocity erosion of $\mathrm{Cr} 3 \mathrm{C} 2-\mathrm{NiCr}$ thermal spray coatings: Part 1 - As-sprayed coatings, Surf. Coatings Technol. 203 (2009) 1086-1093.

[10] A. Ibrahim, C.C. Berndt, Fatigue and deformation of HVOF sprayed WC-Co coatings and hard chrome plating, Mater. Sci. Eng. A. 456 (2007) 114-119.

[11] G. Bolelli, R. Giovanardi, L. Lusvarghi, T. Manfredini, Corrosion resistance of HVOF-sprayed coatings for hard chrome replacement, Corros. Sci. 48 (2006) 3375-3397.

[12] J.G. La Barbera-Sosa, Y.Y. Santana, C. Villalobos-Gutiérrez, D. Chicot, J. Lesage, X. Decoopman, et al., Fatigue behavior of a structural steel coated with a WC-10Co-4Cr/Colmonoy 88 deposit by HVOF thermal spraying, Surf. Coatings Technol. 220 (2013) 248-256.

[13] L. Thakur, N. Arora, R. Jayaganthan, R. Sood, An investigation on erosion behavior of HVOF sprayed WC-CoCr coatings, Appl. Surf. Sci. 258 (2011) 1225-1234.

[14] M.R. Ramesh, S. Prakash, S.K. Nath, P.K. Sapra, B. Venkataraman, Solid particle erosion of HVOF sprayed WC-Co/NiCrFeSiB coatings, Wear. 269 (2010) 197-205.

[15] D. Kumar Goyal, H. Singh, H. Kumar, V. Sahni, Slurry erosion behaviour of HVOF sprayed WC$10 \mathrm{Co}-4 \mathrm{Cr}$ and Al 20 3+13TiO 2 coatings on a turbine steel, Wear. 289 (2012) 46-57.

[16] M. Manjunatha, R.S. Kulkarni, M. Krishna, Investigation of HVOF Thermal sprayed $\mathrm{Cr} 3 \mathrm{C} 2$ $\mathrm{NiCr}$ Cermet Carbide Coatings on Erosive Performance of AISI 316 Molybdenum steel, 5 (2014) 622-629.

[17] H.S. Grewal, H. Singh, A. Agrawal, Understanding Liquid Impingement erosion behaviour of nickel-alumina based thermal spray coatings, Wear. 301 (2013) 424-433.

[18] M. Akhtari Zavareh, A.A.D.M. Sarhan, B.B. Razak, W.J. Basirun, The tribological and electrochemical behavior of HVOF-sprayed $\mathrm{Cr} 3 \mathrm{C} 2-\mathrm{NiCr}$ ceramic coating on carbon steel, Ceram. Int. 41 (2015) 5387-5396.

[19] L. Thakur, N. Arora, A comparative study on slurry and dry erosion behaviour of HVOF sprayed WC-CoCr coatings, Wear. 303 (2013) 405-411.

[20] M.A. Islam, T. Alam, Z.N. Farhat, A. Mohamed, A. Alfantazi, Effect of microstructure on the erosion behavior of carbon steel, Wear. 332-333 (2015) 1080-1089.

[21] N. Andrews, L. Giourntas, A.M. Galloway, A. Pearson, Effect of impact angle on the slurry erosion-corrosion of Stellite 6 and SS316, Wear. 320 (2014) 143-151.

[22] Z.B. Zheng, Y.G. Zheng, W.H. Sun, J.Q. Wang, Erosion-corrosion of HVOF-sprayed Fe-based amorphous metallic coating under impingement by a sand-containing $\mathrm{NaCl}$ solution, Corros. Sci. 76 (2013) 337-347.

[23] Oerlikon Metco, Material Product Data Sheet Tungsten Carbide - $10 \%$ Cobalt 4 \% Chromium Powders, (2015) 1-7.

[24] Oerlikon Metco, Material Product Data Sheet Chromium Carbide - Nickel Chromium Powder Blends, 2 (2014) 2-7.

[25] Praxair, Materials Product Data Sheet Al-1110-HP, (1999) 1-4.

[26] International ASTM Standard, ASTM E2109 - 01 (2014): Standard Test Methods for Determining Area Percentage Porosity in Thermal Sprayed Coatings, (2006) 1-8.

[27] F. Cernuschi, S. Capelli, C. Guardamagna, L. Lorenzoni, D.E. Mack, A. Moscatelli, Solid particle erosion of standard and advanced thermal barrier coatings, Wear. 348-349 (2015) 43-51.

[28] R.E. Vieira, A. Mansouri, B.S. McLaury, S.A. Shirazi, Experimental and computational study of erosion in elbows due to sand particles in air flow, Powder Technol. 288 (2016) 339-353.

[29] GE Aircraft Engines, E50TF121 - S2: Room Temperature Erosion Test Method for Coatings, 
(1995) 1-11.

[30] Shabana, M.M.M. Sarcar, K.N.S. Suman, S. Kamaluddin, Tribological and Corrosion behavior of HVOF Sprayed WC-Co, NiCrBSi and Cr3C2-NiCr Coatings and analysis using Design of Experiments, Mater. Today Proc. 2 (2015) 2654-2665.

[31] A. Neville, T. Hodgkiess, J.T. Dallas, A study of the erosion-corrosion behaviour of engineering steels for marine pumping applications, Wear. 186-187 (1995) 497-507.

[32] Y. Zhao, F. Zhou, J. Yao, S. Dong, N. Li, Erosion-corrosion behavior and corrosion resistance of AISI 316 stainless steel in flow jet impingement, Wear. 328-329 (2015) 464-474.

[33] X. Jiang, Y.G. Zheng, W. Ke, Effect of flow velocity and entrained sand on inhibition performances of two inhibitors for $\mathrm{CO} 2$ corrosion of $\mathrm{N} 80$ steel in $3 \% \mathrm{NaCl}$ solution, Corros. Sci. 47 (2005) 2636-2658.

[34] Q. Yang, T. Senda, A. Ohmori, Effect of carbide grain size on microstructure and sliding wear behavior of HVOF-sprayed WC-12\% Co coatings, Wear. 254 (2003) 23-34.

[35] P. Chivavibul, M. Watanabe, S. Kuroda, K. Shinoda, Effects of carbide size and Co content on the microstructure and mechanical properties of HVOF-sprayed WC-Co coatings, Surf. Coatings Technol. 202 (2007) 509-521.

[36] C.J. Li, Y.Y. Wang, G.J. Yang, A. Ohmori, K.A. Khor, Effect of solid carbide particle size on deposition behaviour, microstructure and wear performance of HVOF cermet coatings, Mater. Sci. Technol. 20 (2004).

[37] C.J. Li, G.J. Yang, Relationships between feedstock structure, particle parameter, coating deposition, microstructure and properties for thermally sprayed conventional and nanostructured WC-Co, Int. J. Refract. Met. Hard Mater. 39 (2013) 2-17.

[38] W. Tillmann, B. Hussong, T. Priggemeier, S. Kuhnt, N. Rudak, H. Weinert, Influence of parameter variations on WC-Co splat formation in an HVOF process using a new beamshutter device, J. Therm. Spray Technol. 22 (2013) 250-262.

[39] W. Liu, F. Shieu, W. Hsiao, Enhancement of wear and corrosion resistance of iron-based hard coatings deposited by high-velocity oxygen fuel (HVOF) thermal spraying, Surf. Coat. Technol. 249 (2014) 24-41.

[40] C. Sun, L. Guo, G. Lu, Y. Lv, F. Ye, Interface bonding between particle and substrate during HVOF spraying, Appl. Surf. Sci. 317 (2014) 908-913.

[41] R. Ahmed, Contact fatigue failure modes of HVOF coatings, Wear. 253 (2002) 473-487.

[42] Struers, Metallographic preparation of thermal spray coatings, 2014.

[43] A. Kulkarni, J. Gutleber, S. Sampath, A. Goland, W.B. Lindquist, H. Herman, et al., Studies of the microstructure and properties of dense ceramic coatings produced by high-velocity oxygen-fuel combustion spraying, Mater. Sci. Eng. A. 369 (2004) 124-137.

[44] I. Finnie, Some Reflections on the Past and Future of Erosion, Wear. 186-187 (1995) 1-10.

[45] P. Kulu, I. Hussainova, R. Veinthal, Solid particle erosion of thermal sprayed coatings, Wear. 258 (2005) 488-496.

[46] H.M. Clark, L.C. Burmeister, The influence of the squeeze film on particle impact velocities in erosion, Int. J. Impact Eng. 12 (1992) 415-426.

[47] K.K. Wong, H.M. Clark, A model of particle velocities and trajectories in a slurry pot erosion tester, Wear. 160 (1993) 95-104.

[48] H.. Hawthorne, B. Arsenault, J.. Immarigeon, J.. Legoux, V.. Parameswaran, Comparison of slurry and dry erosion behaviour of some HVOF thermal sprayed coatings, Wear. 225-229 
(1999) 825-834.

[49] A. V. Levy, P. Chik, The effects of erodent composition and shape on the erosion of steel, Wear. 89 (1983) 151-162.

[50] S. Lathabai, M. Ottmüller, I. Fernandez, Solid particle erosion behaviour of thermal sprayed ceramic, metallic and polymer coatings, Wear. 221 (1998) 93-108.

[51] M. Liebhard, A. Levy, Effect of erodent particle characteristics on the erosion of metals, Wear. 151 (1991) 381-390.

[52] Y.I. Oka, H. Ohnogi, T. Hosokawa, M. Matsumura, The impact angle dependence of erosion damage caused by solid particle impact, Wear. 203-204 (1997) 573-579.

[53] I. Finnie, Erosion of surfaces by solid particles, Wear. 3 (1960) 87-103.

[54] V.A.D. Souza, A. Neville, Corrosion and synergy in a WC-Co-Cr HVOF thermal spray coating Understanding their role in erosion-corrosion degradation, Wear. 259 (2005) 171-180.

[55] V. Fervel, B. Normand, H. Liao, C. Coddet, E. Beche, R. Berjoan, Friction and wear mechanisms of thermally sprayed ceramic and cermet coatings, Surf. Coatings Technol. 111 (1999) 255262.

[56] C. Verdon, A. Karimi, J.L. Martin, Microstructural and analytical study of thermally sprayed WC-Co coatings in connection with their wear resistance, Mater. Sci. Eng. A. 234-236 (1997) 731-734.

[57] R.J.K. Wood, Tribology of thermal sprayed WC-Co coatings, Int. J. Refract. Met. Hard Mater. 28 (2010) 82-94.

[58] A. Neville, F. Reza, S. Chiovelli, T. Revega, Erosion-corrosion behaviour of WC-based MMCs in liquid-solid slurries, in: Wear, 2005: pp. 181-195.

[59] S. Hong, Y. Wu, Q. Wang, G. Ying, G. Li, W. Gao, et al., Microstructure and cavitation-silt erosion behavior of high-velocity oxygen-fuel (HVOF) sprayed $\mathrm{Cr} 3 \mathrm{C} 2-\mathrm{NiCr}$ coating, Surf. Coatings Technol. 225 (2013) 85-91.

[60] K. Yang, J. Rong, C. Liu, H. Zhao, S. Tao, C. Ding, Study on erosion-wear behavior and mechanism of plasma-sprayed alumina-based coatings by a novel slurry injection method, Tribol. Int. 93 (2016) 29-35. 
Fig 1. Schematic diagram of dry erosion test rig (not to scale). (1) Sand blasting gun; (2) Particle hopper; (3) Rig fixture; (4) Jet nozzle; (5) Particle stream; (6) Test specimen; (7) Sample holder.

Fig 2. Schematic diagram of recirculating liquid impingement test rig (not to scale). (1) Data logging; (2) Potentiostat; (3) Working electrode; (4) Reference electrode; (5) Auxiliary electrode; (6) Recirculating pump (pump 1); (7) Sample holder; (8) Jet impingement nozzle; (9) Specimen; (10) Slurry solution; (11) Slurry tank; (12) Drainage valve; (13) Drainage pump (pump 2).

Fig 3. Jet nozzle and specimen in-situ for liquid impingement at $20^{\circ}$ angle of attack.

Fig 4. a) Optical image of HVOF deposited WC-CoCr coating [x200, Unetched], b) enhanced magnification of WC-CoCr $[\times 1000$, Unetched].

Fig 5. Scanning electron micrograph of a) WC-CoCr coating [x200], b) $\mathrm{Cr}_{3} \mathrm{C}_{2}-\mathrm{NiCr}$ coating [x350].

Fig 6. Optical image of a) HVOF deposited $\mathrm{Cr}_{3} \mathrm{C}_{2}-\mathrm{NiCr}$ coating [x200, Unetched], b) Enhanced magnification of $\mathrm{Cr}_{3} \mathrm{C}_{2}-\mathrm{NiCr}[\mathrm{x} 1000$, Unetched].

Fig 7. $\mathrm{Al}_{2} \mathrm{O}_{3}$ coating a) Light optical micrograph. [x100 Unetched] b) Scanning electron micrograph. [x750].

Fig 8. Micro-hardness measurements through coating thickness.

Fig 9. Average mass and volume loss under dry erosion conditions.

Fig 10. Average mass and volume loss following slurry erosion testing.

Fig 11. Average volume loss with dry and slurry erosion. 
Fig 12. Volume loss with respect to coating hardness following; a) slurry erosion, b) dry erosion.

Fig 13. Macro images of a) Uncoated $\mathrm{S} 355$, b) WC-CoCr, c) $\mathrm{Cr}_{3} \mathrm{C}_{2}-\mathrm{NiCr}$, d) $\mathrm{Al}_{2} \mathrm{O}_{3}$, following 1-hr slurry erosion testing.

Fig 14. Scanning electron micrographs of a) uncoated specimen [x900], b) WC-CoCr [x1500], c) $\mathrm{Cr}_{3} \mathrm{C}_{2}-\mathrm{NiCr}$ $[x 1000]$, d) $\mathrm{Al}_{2} \mathrm{O}_{3}[x 2500]$, following slurry erosion test. 


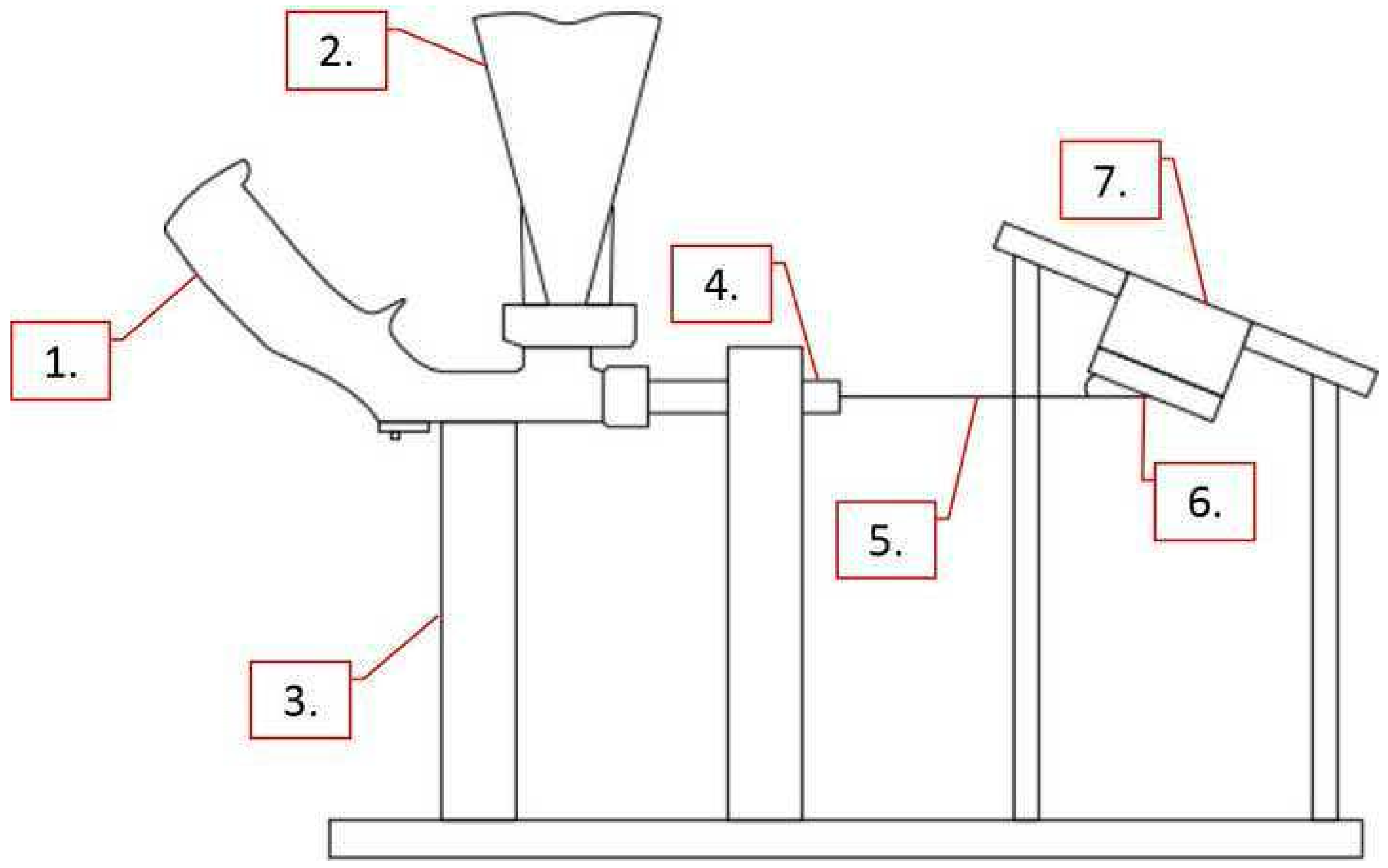




\section{Figure 2}

Click here to download high resolution image

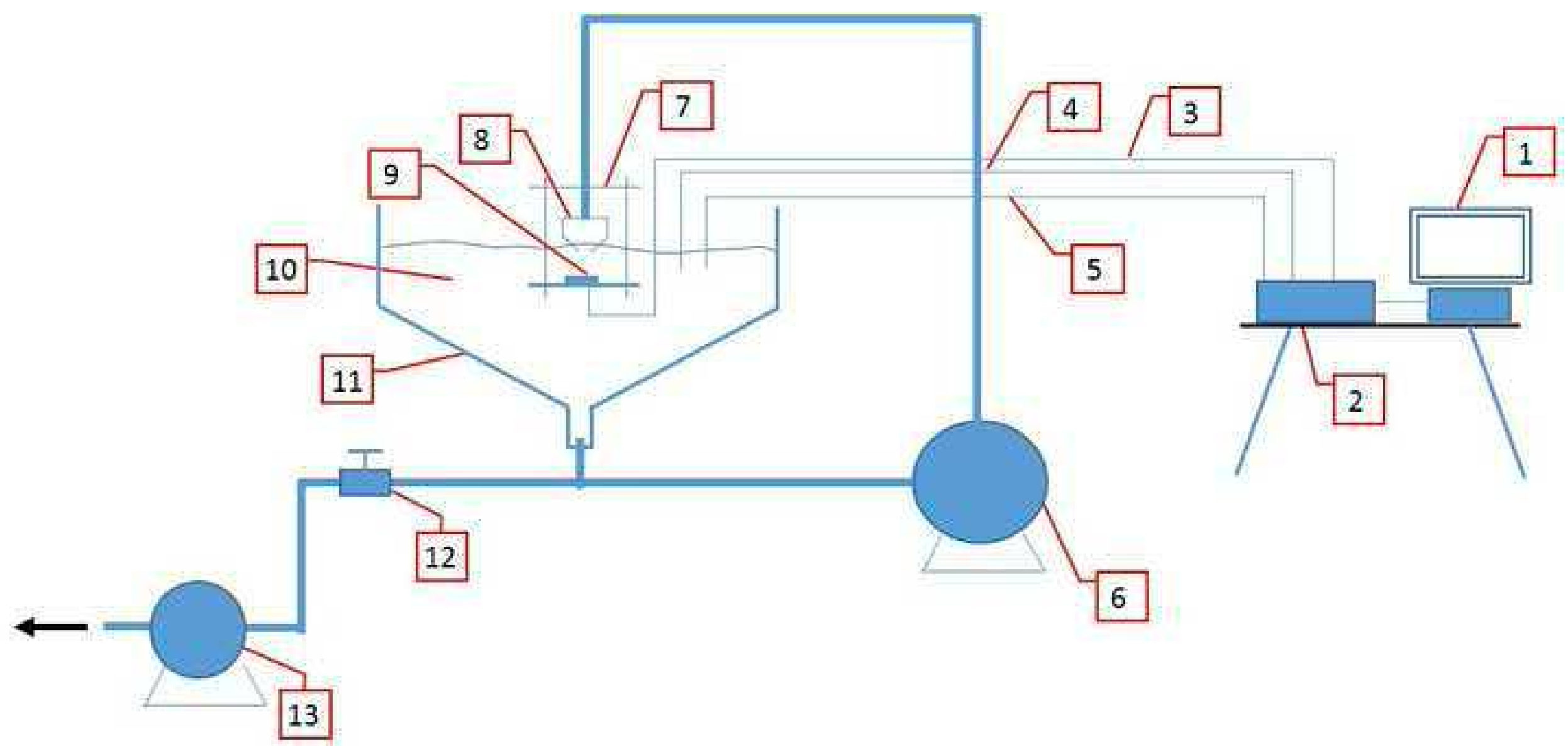


Click here to download high resolution image

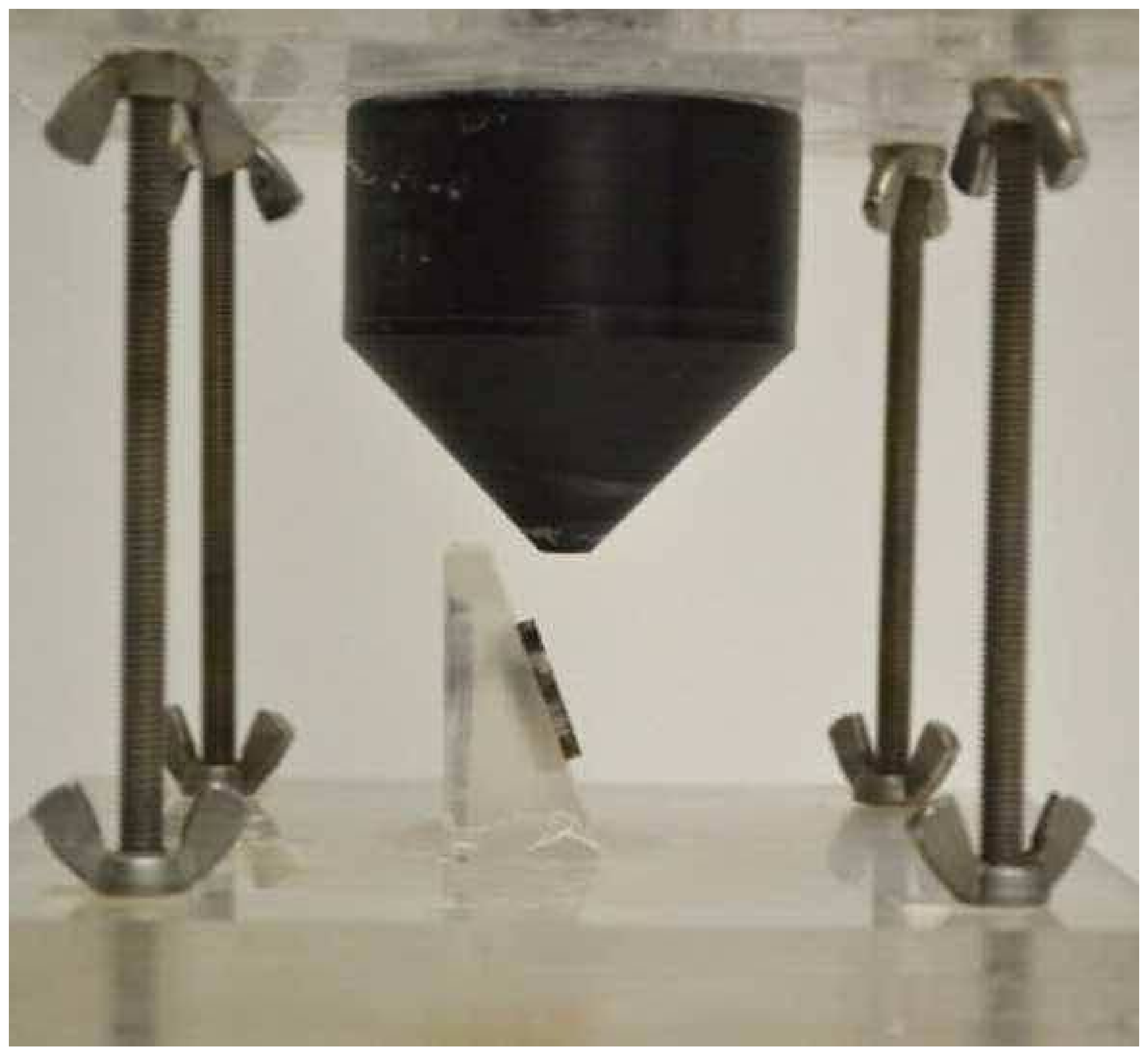




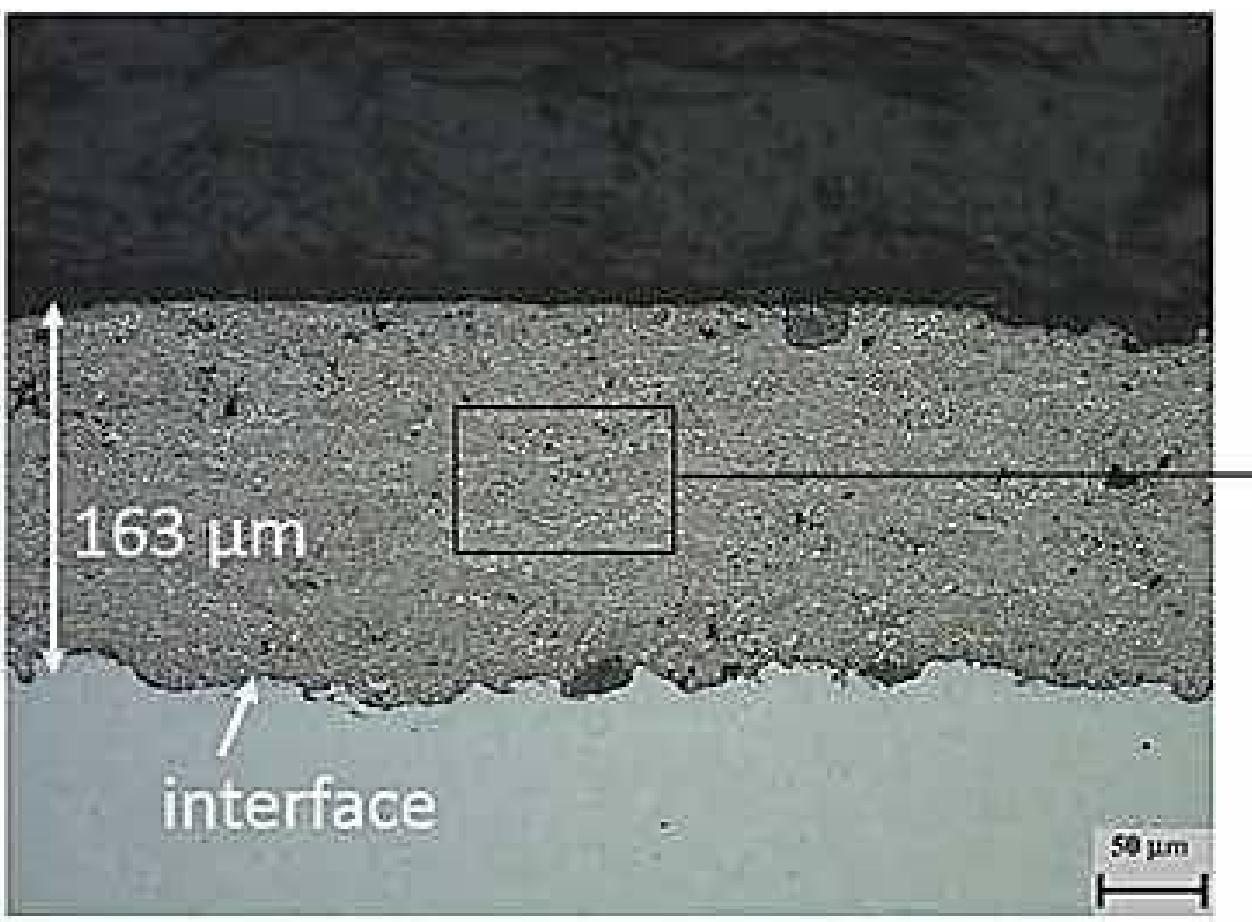

(a)

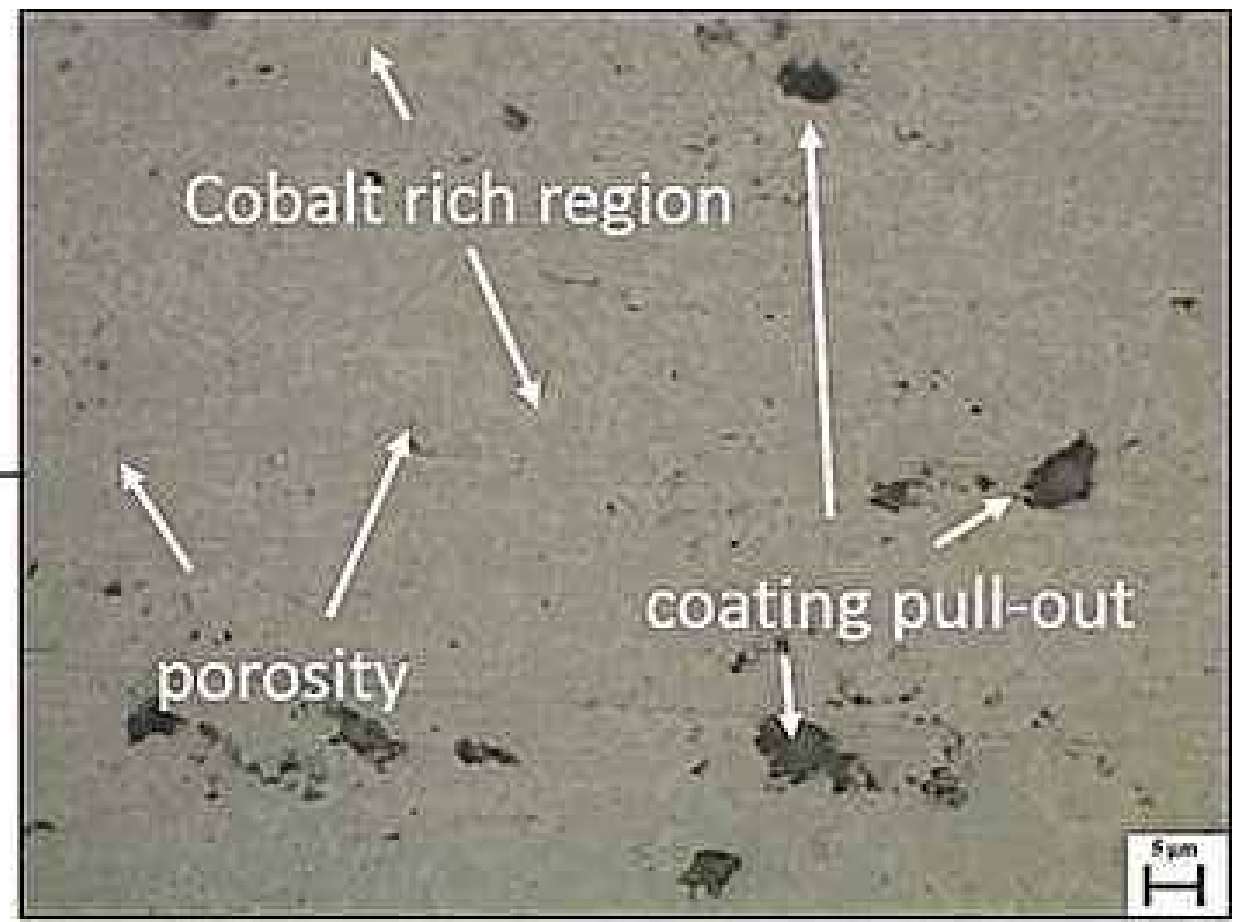

(b) 
Click here to download high resolution image

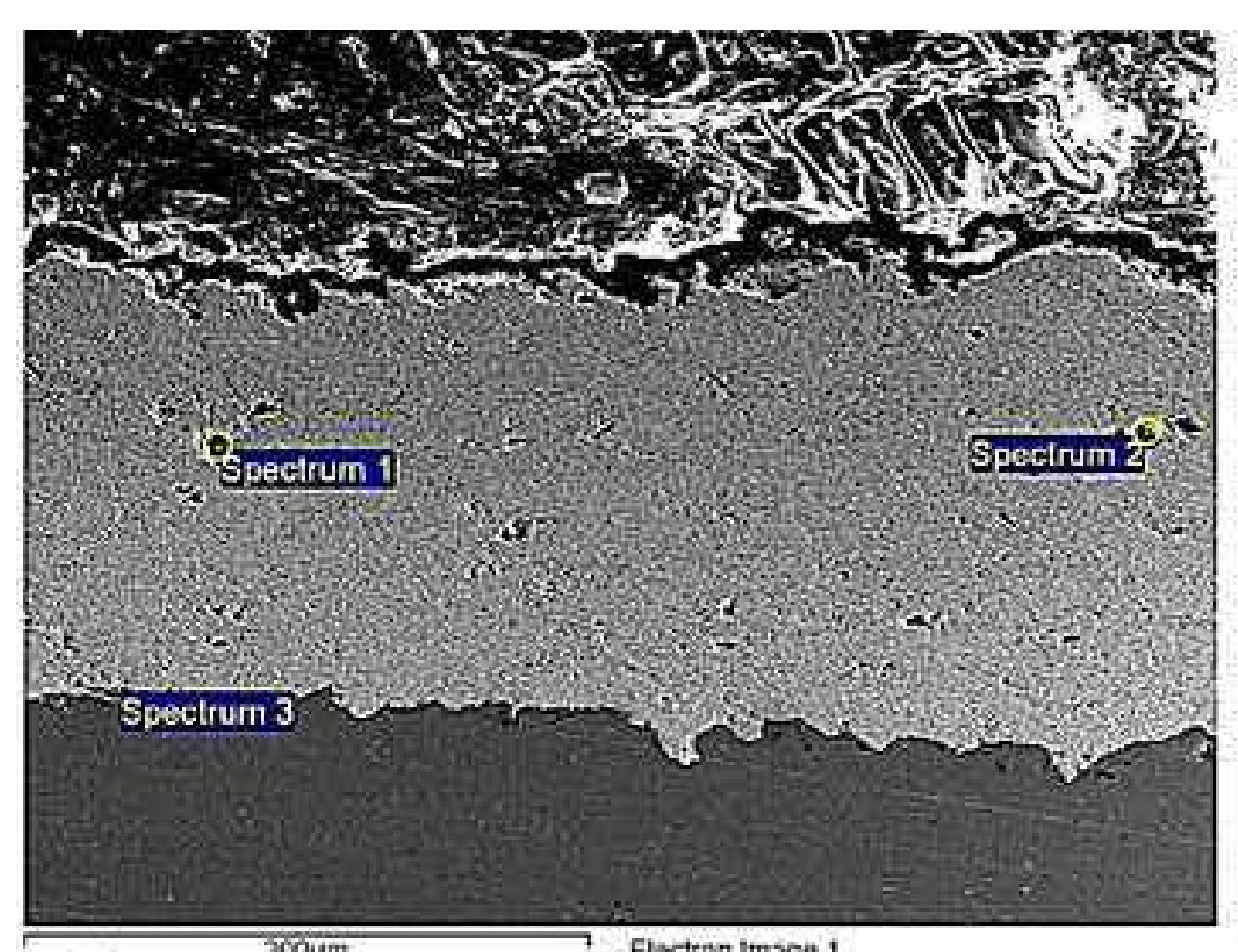

(a) Electron image I

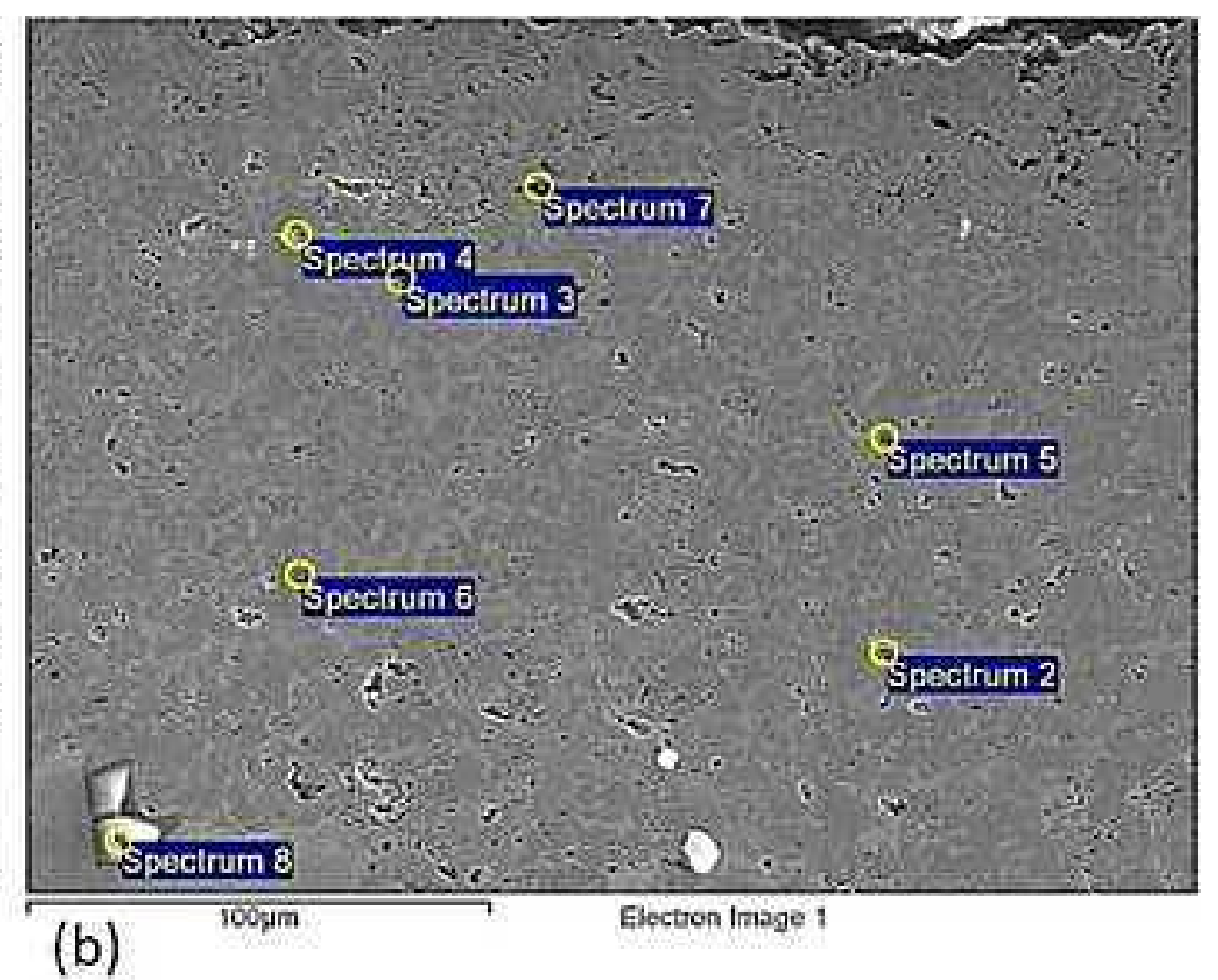

(b)
Electron Irage ? 100\%m
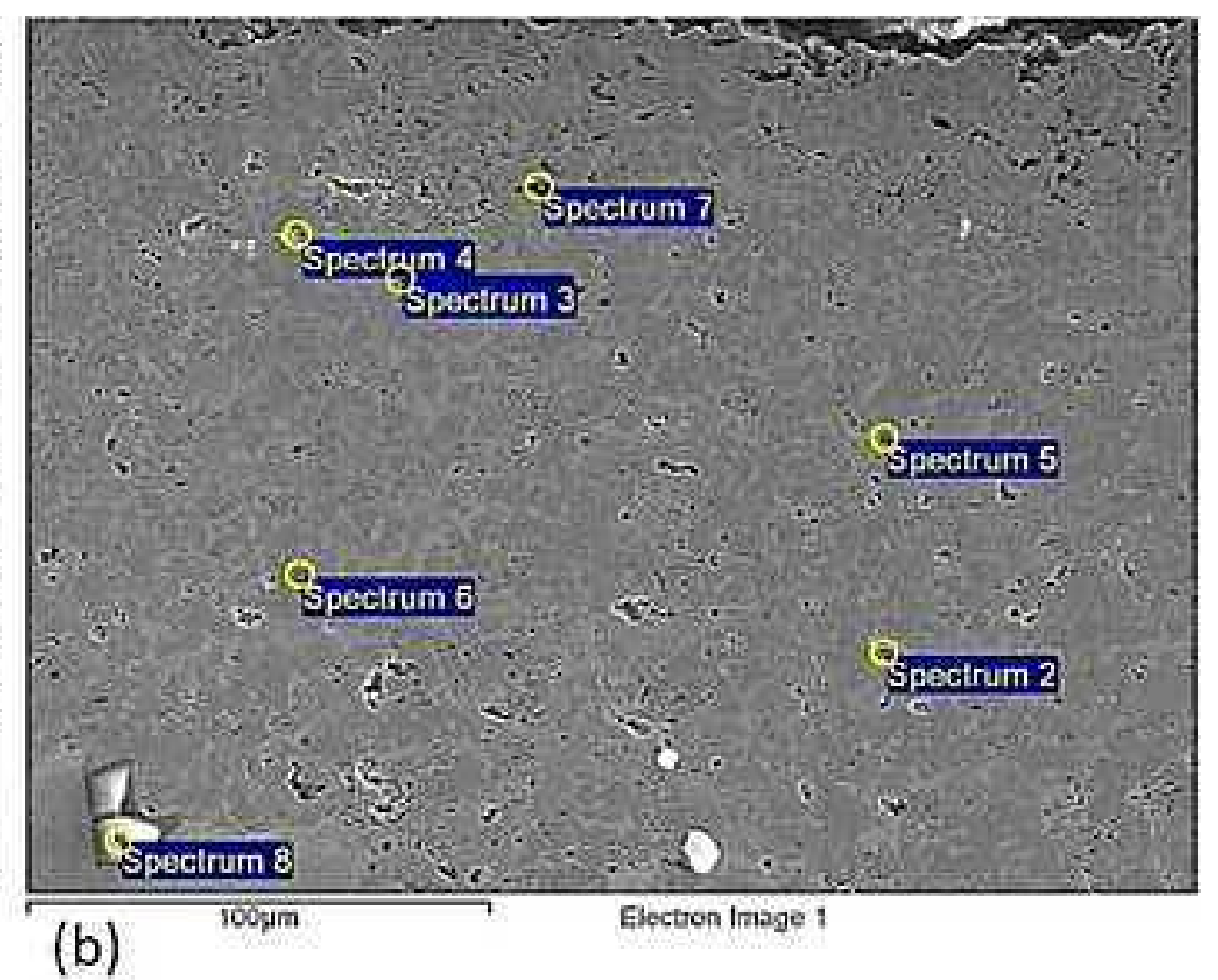


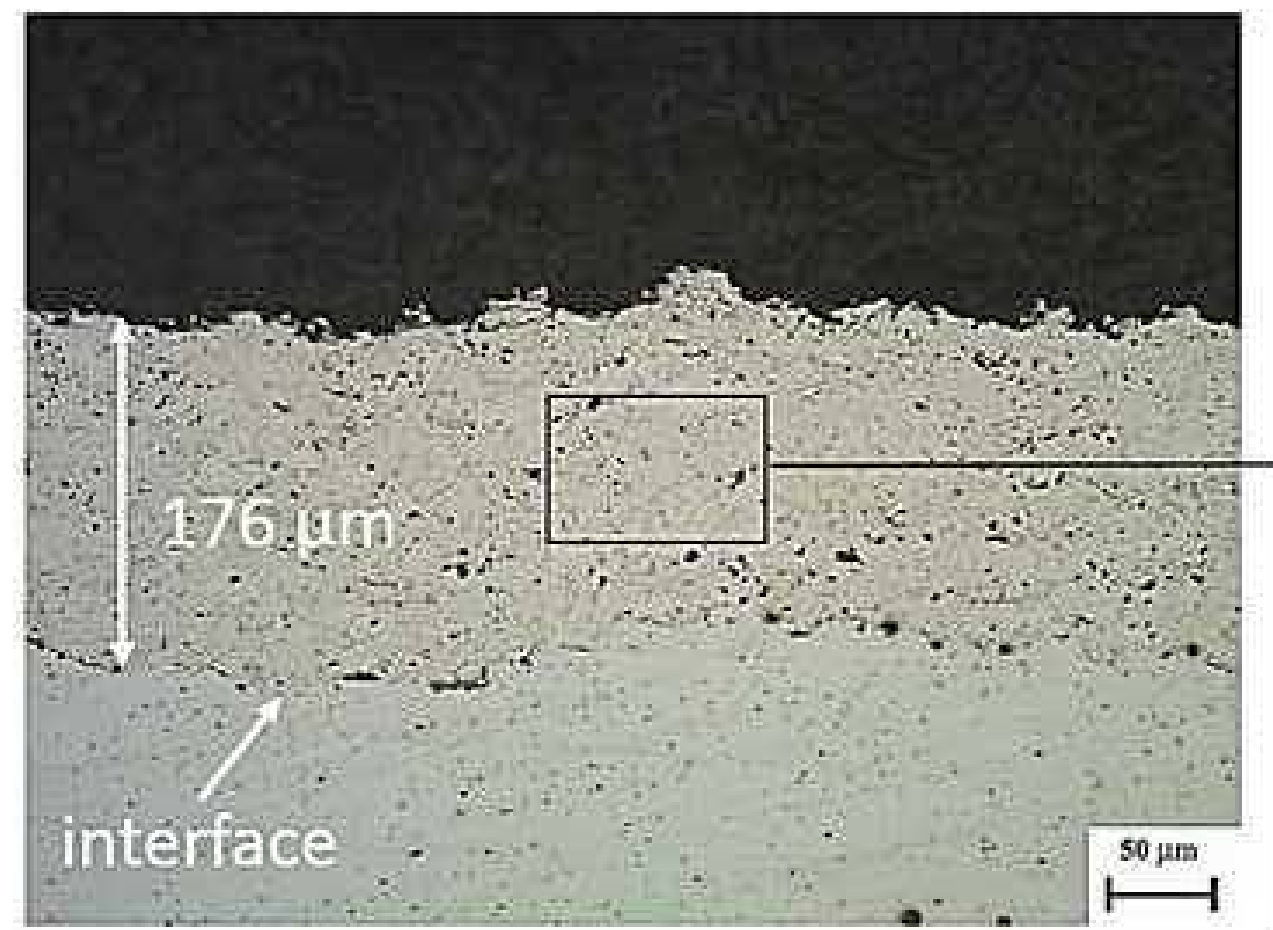

(a)

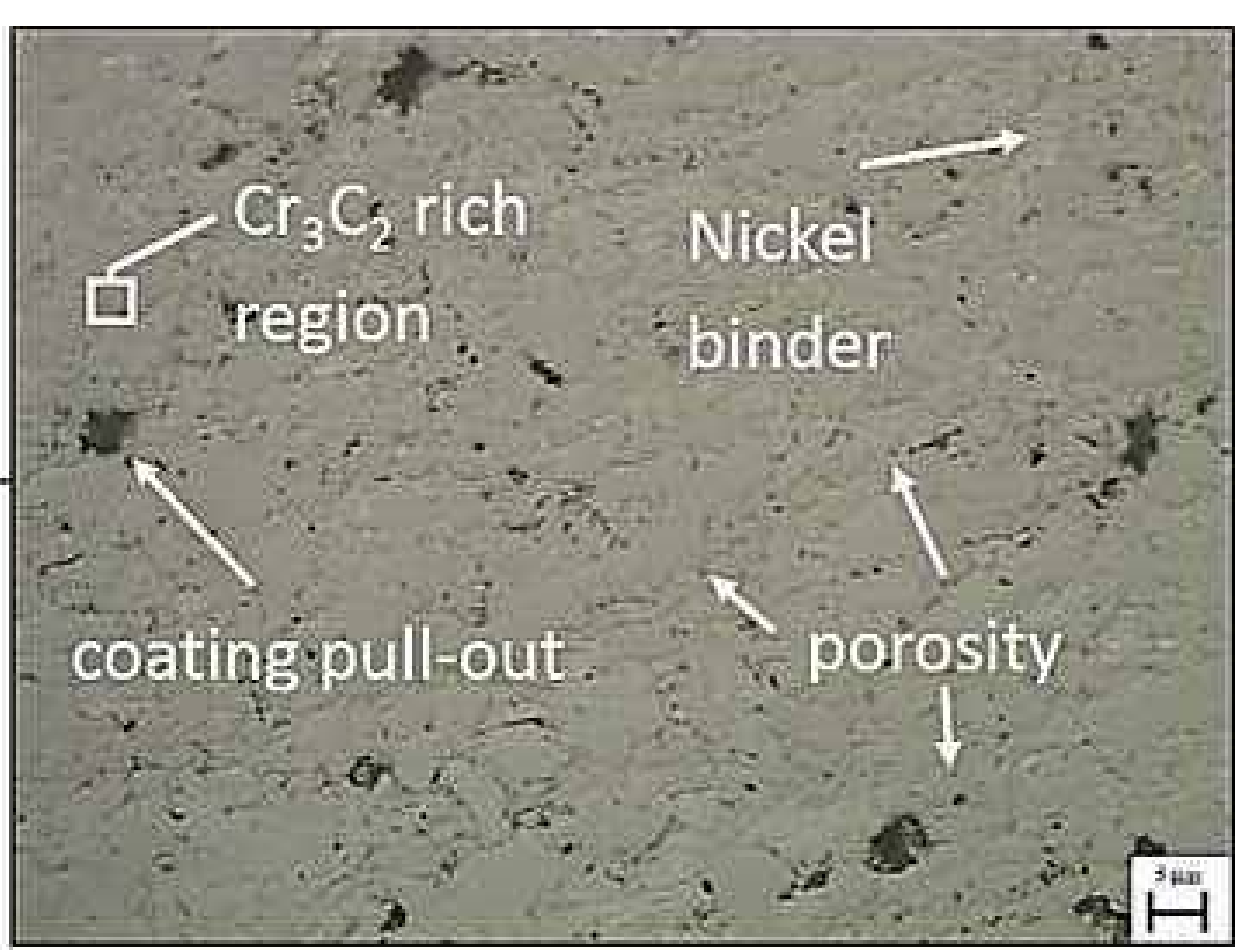

(b) 
Click here to download high resolution image
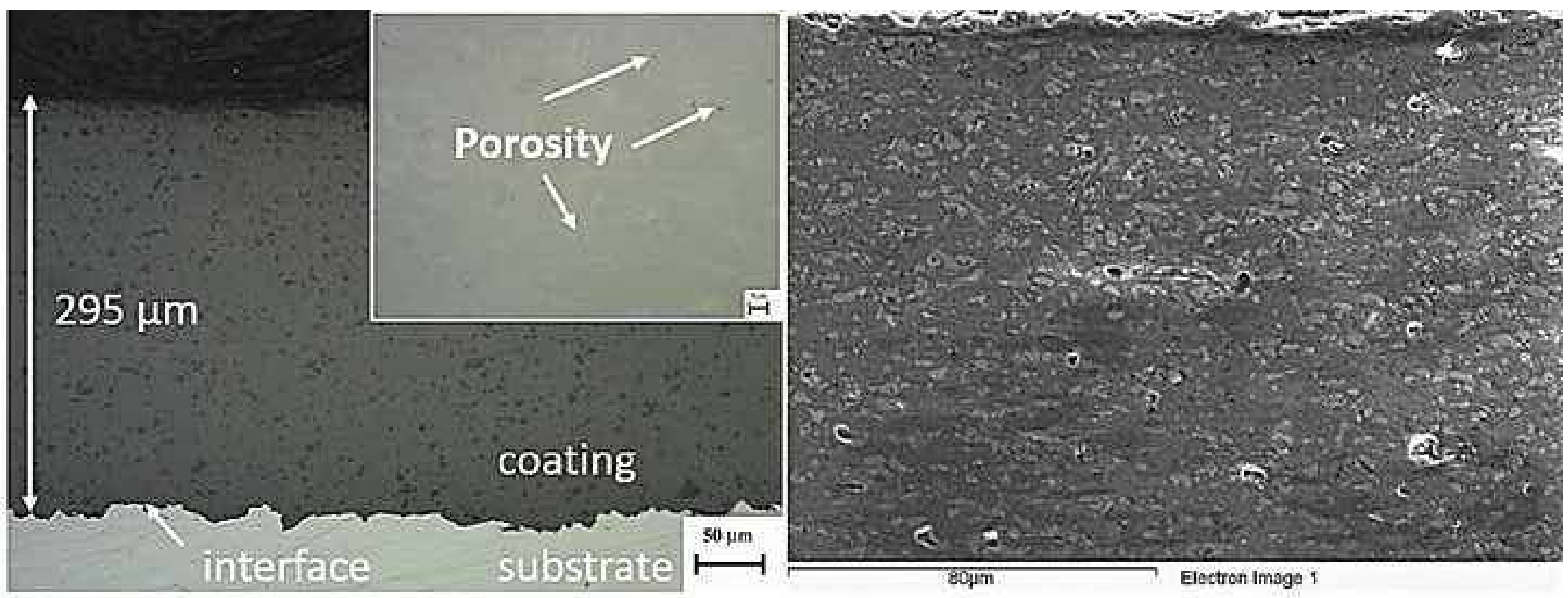

(a)

(b) 
Click here to download Figure: Fig 8.xIsx

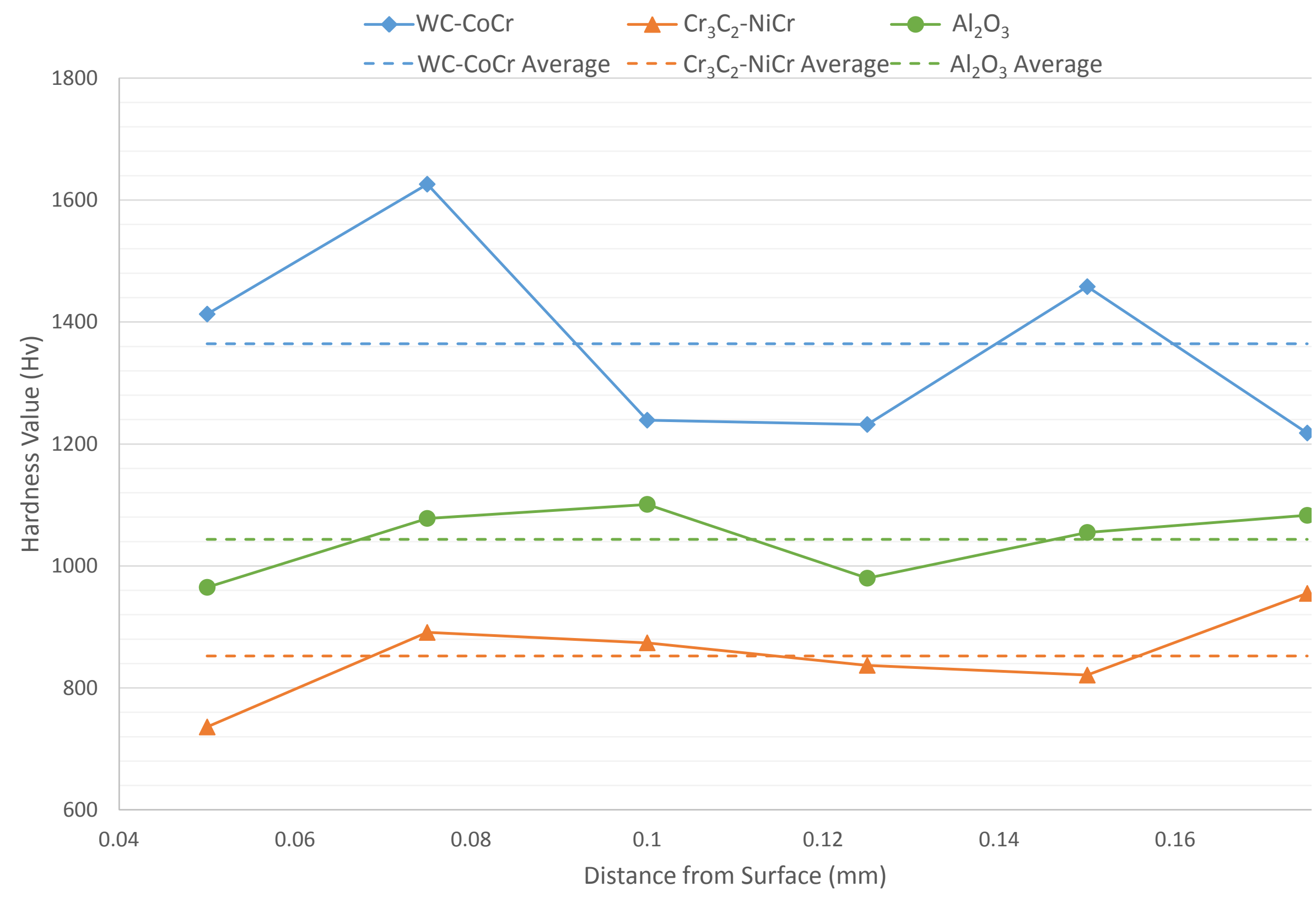


Click here to download Figure: Fig 9.xIsx

- Mass Loss (mg) Volume Loss $\left(\mathrm{mm}^{3}\right)$

60

50

40

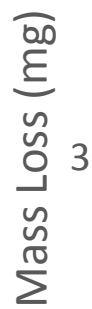

20

10

0

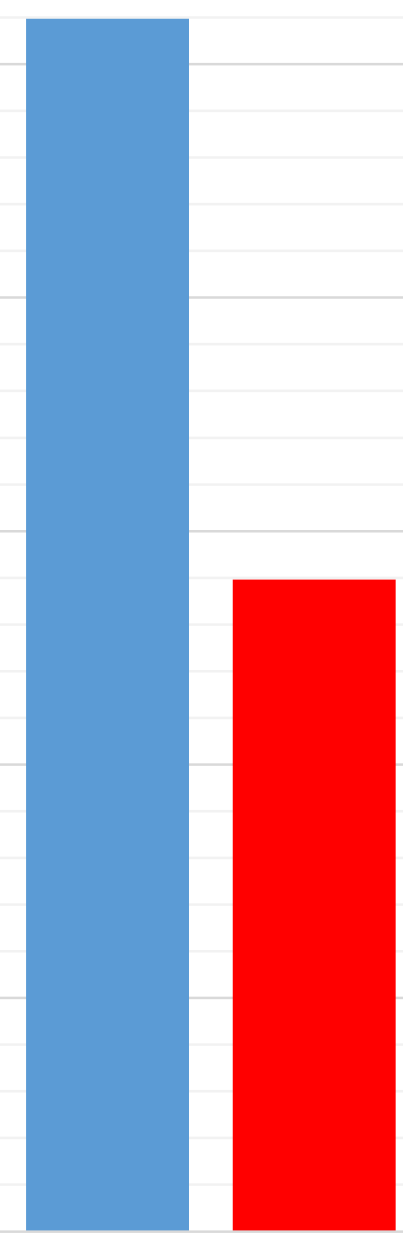

WC-CoCr

$\mathrm{Cr}_{3} \mathrm{C}_{2}-\mathrm{NiCr}$

$\mathrm{Al}_{2} \mathrm{O}_{3}$

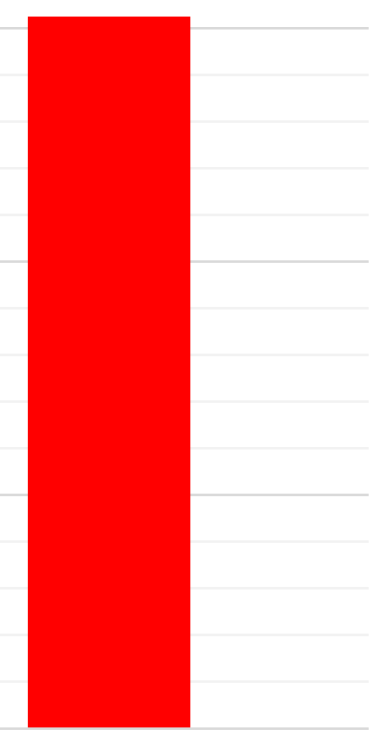


Click here to download Figure: Fig 10.xlsx

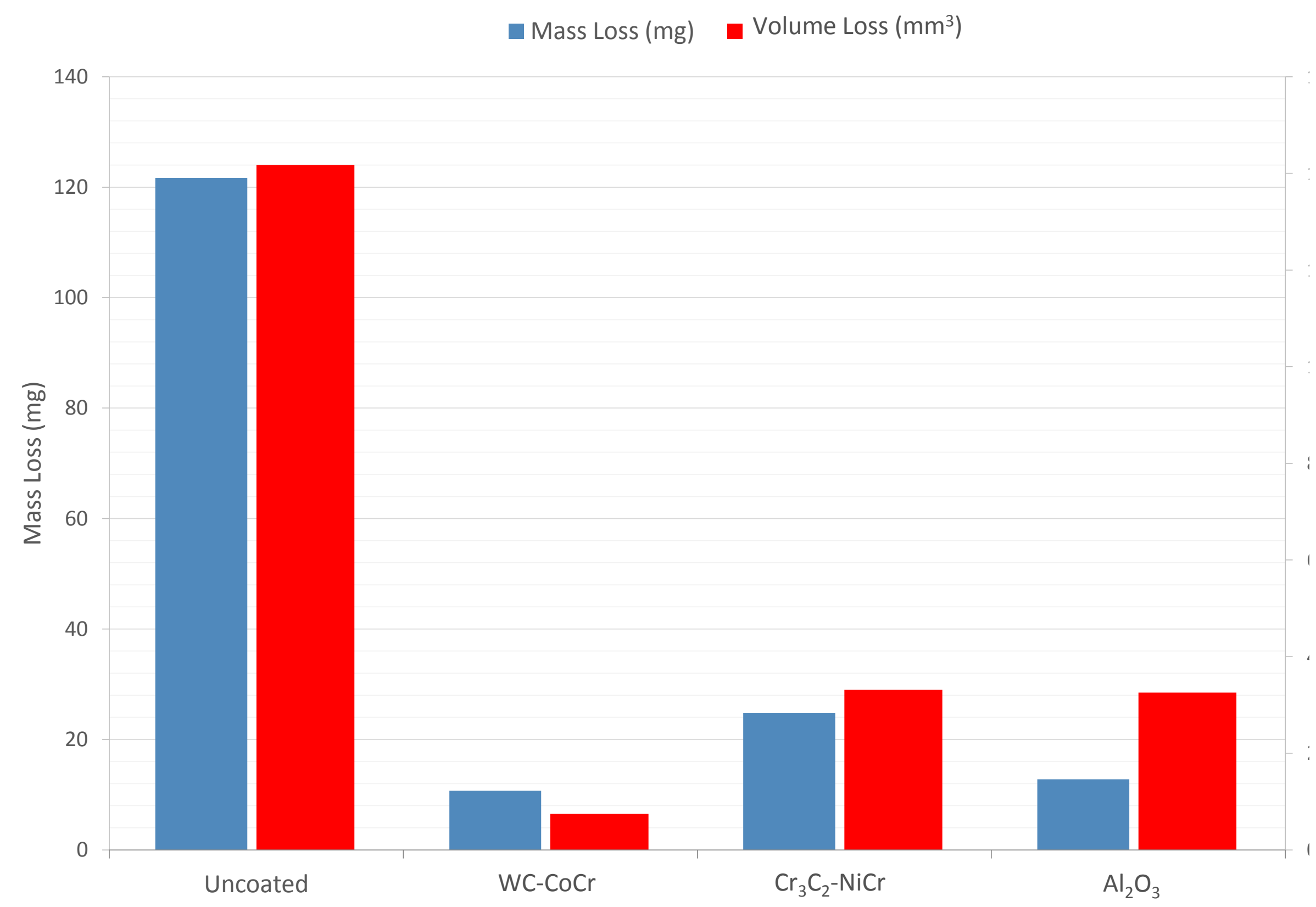


Click here to download Figure: Fig 11.xlsx

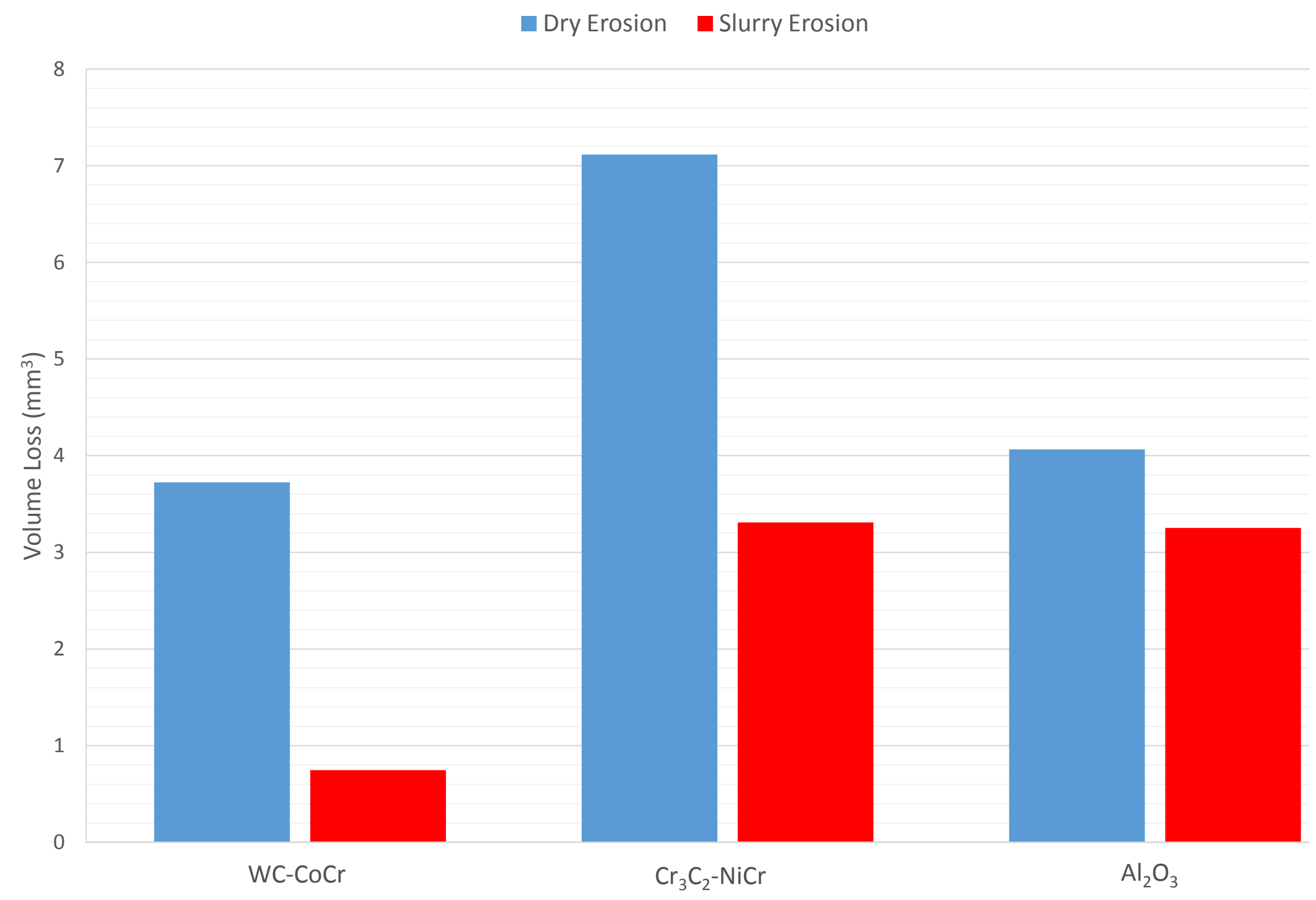




\section{Figure 12a}

Click here to download Figure: Fig 12a.xlsx

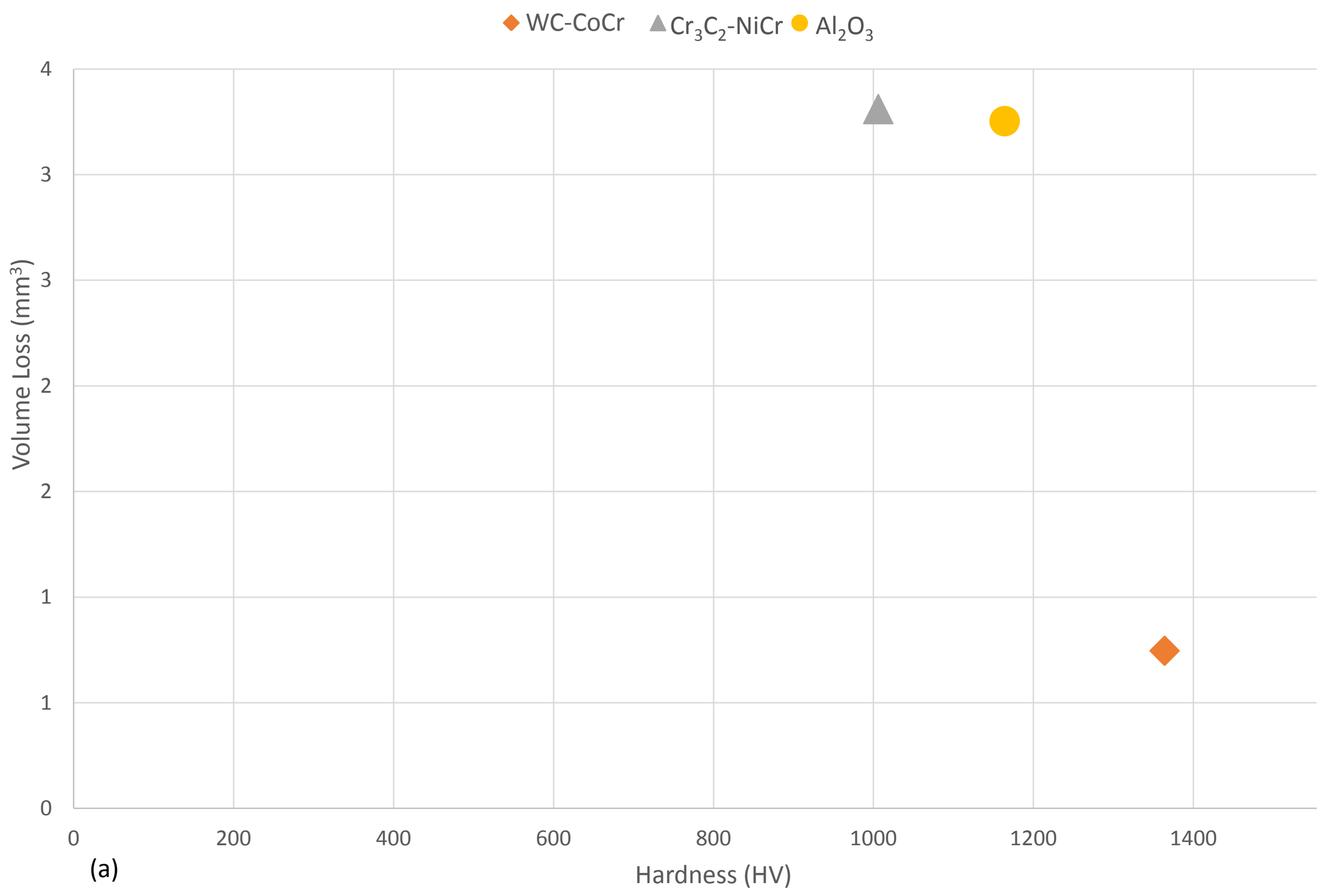




\section{Figure $12 b$}

Click here to download Figure: Fig 12b.xIsx

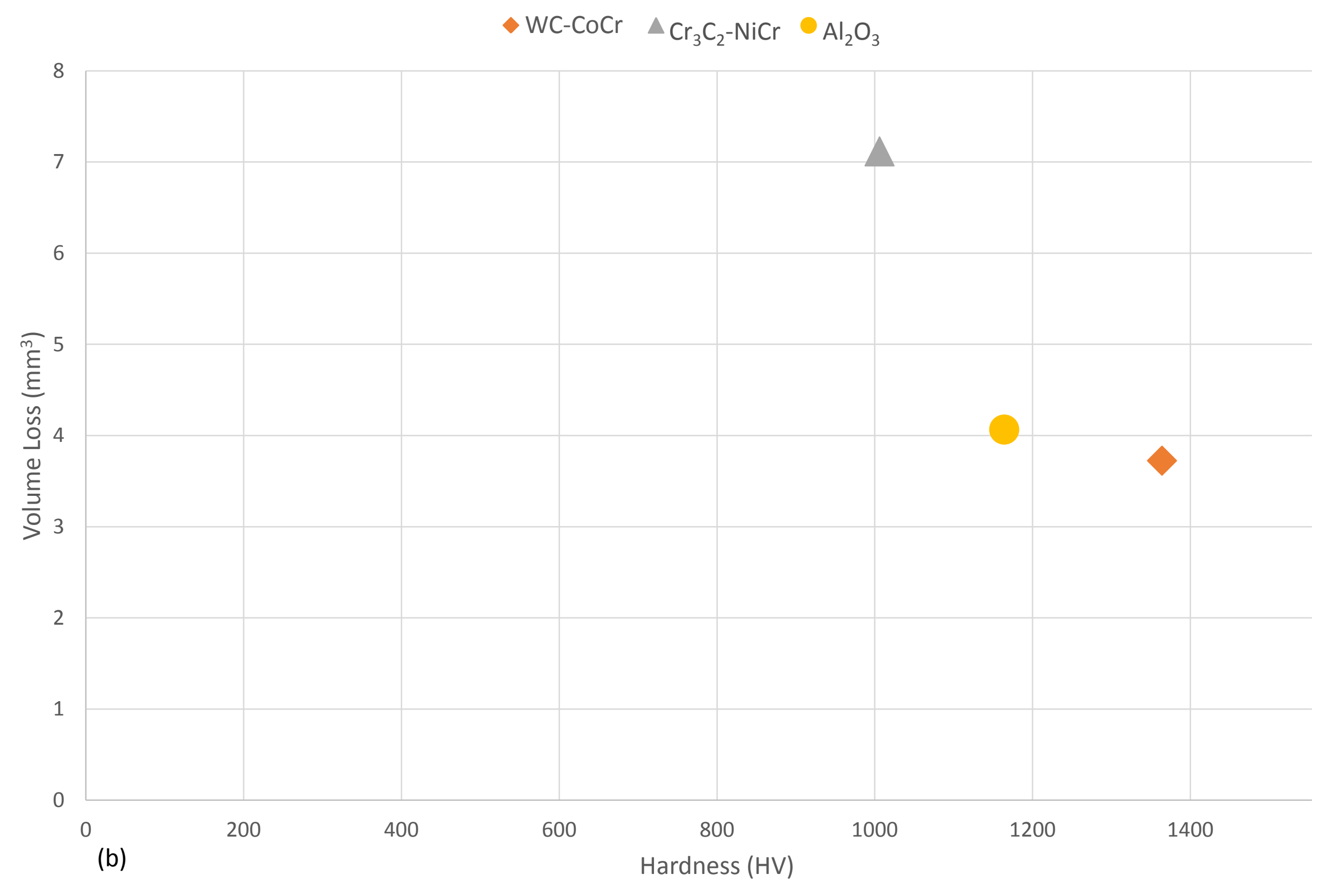


Click here to download high resolution image

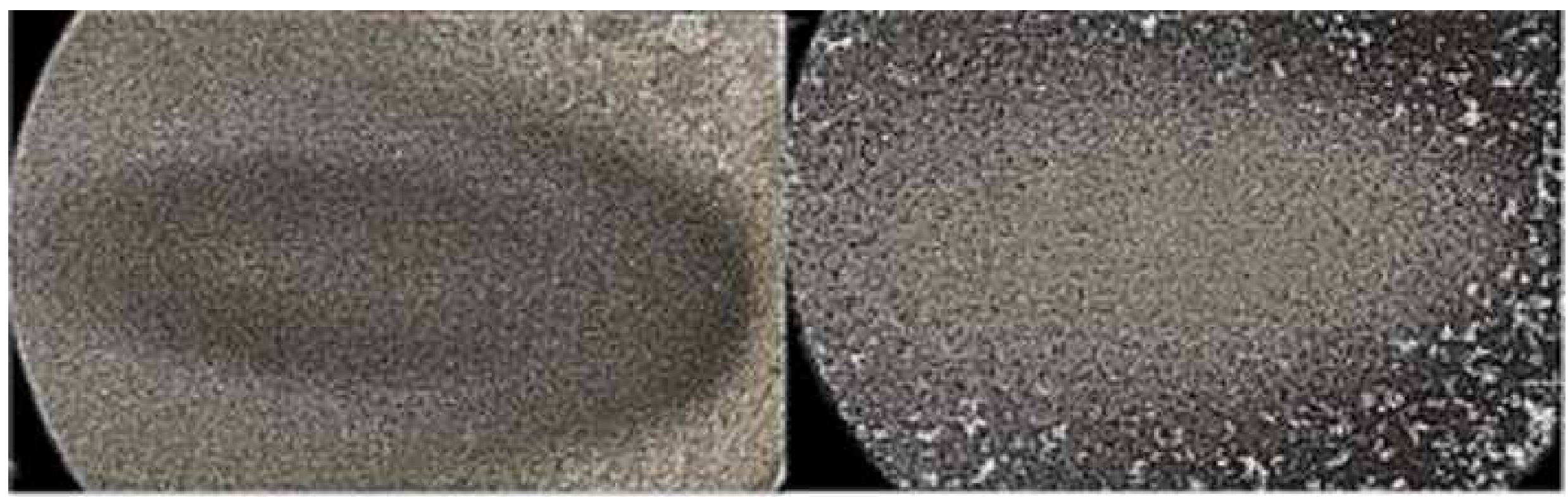

(a)

(b)

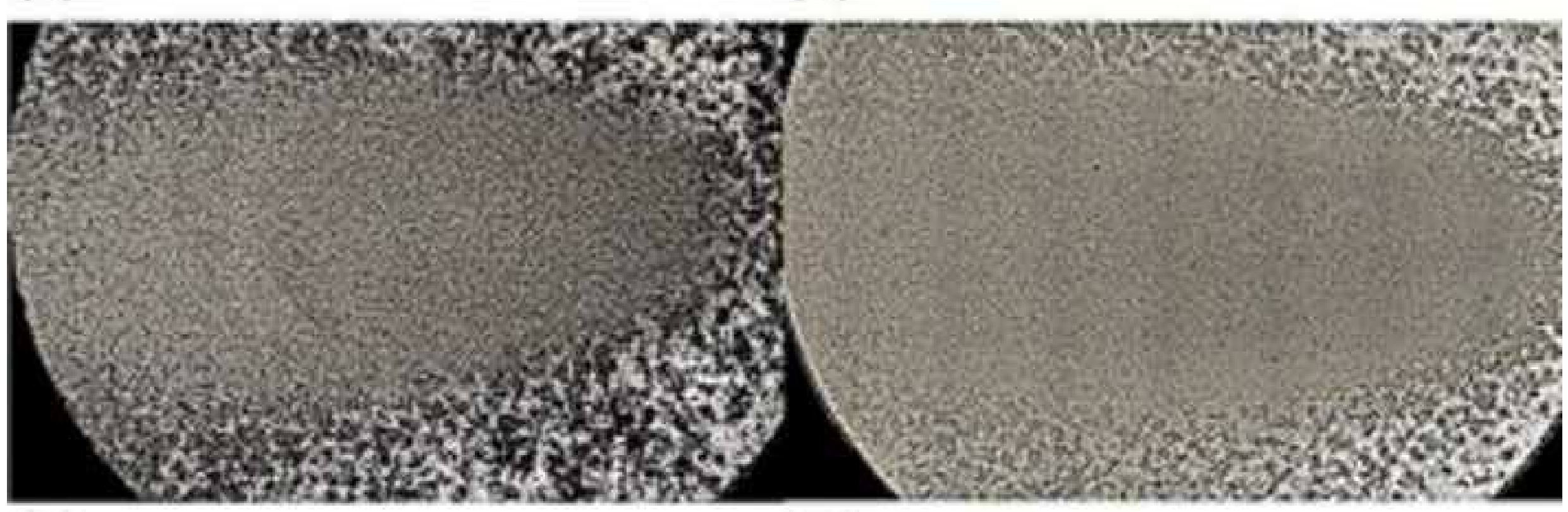

(c)

(d) 
Click here to download high resolution image

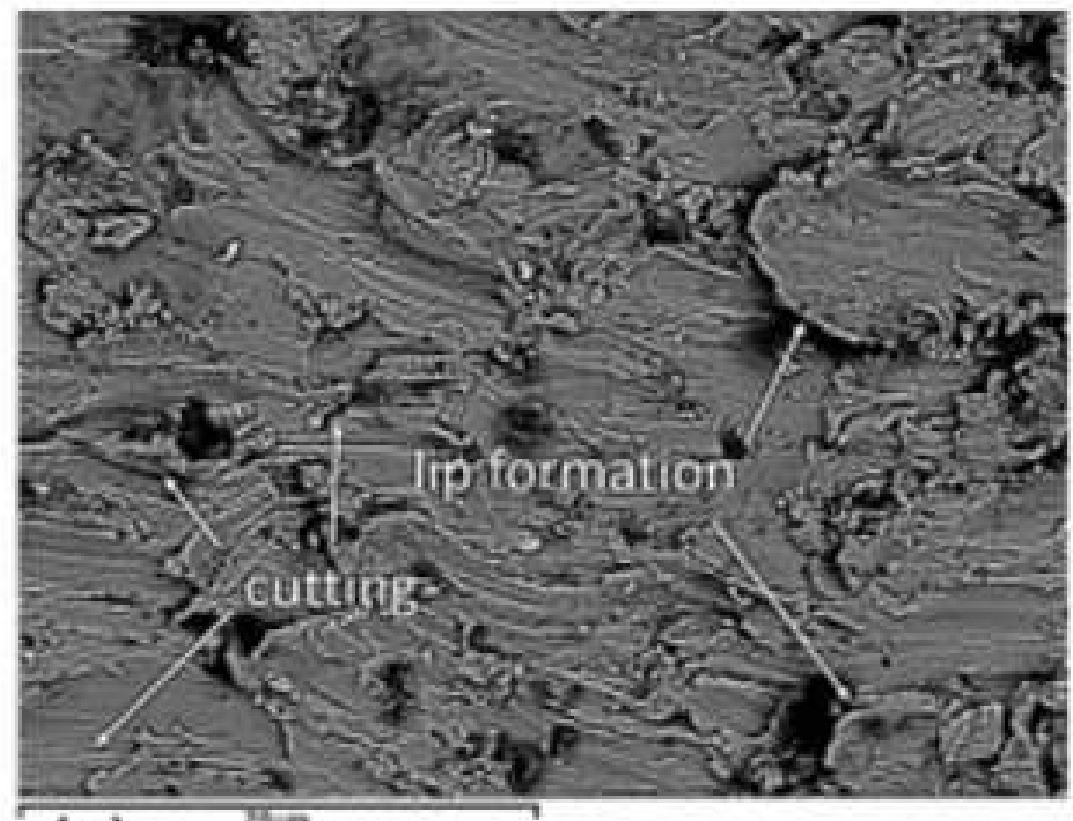

(a)

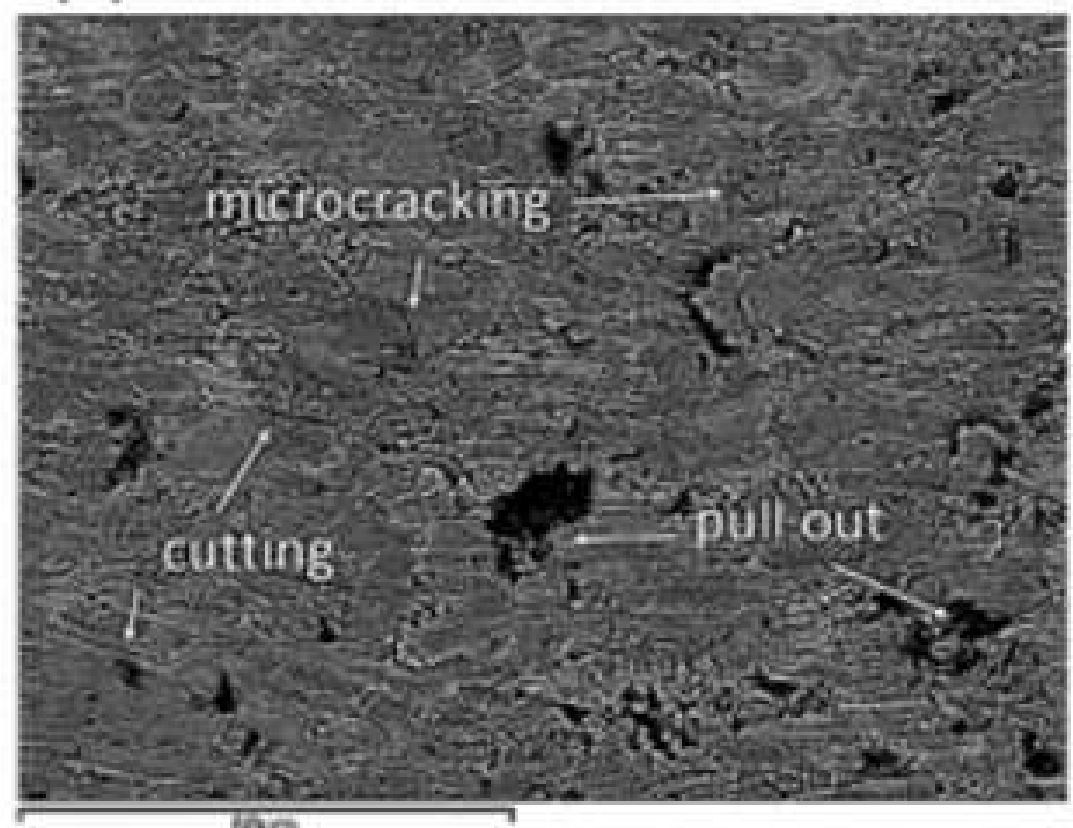

(c)

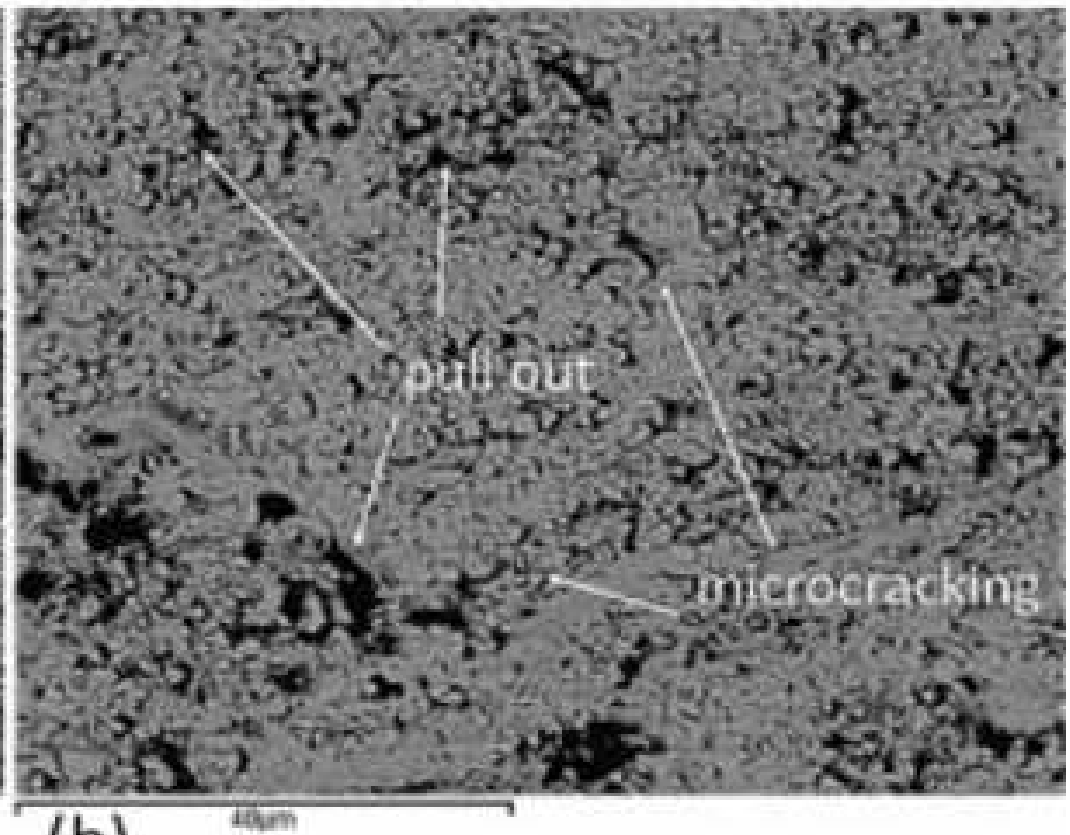

(b)

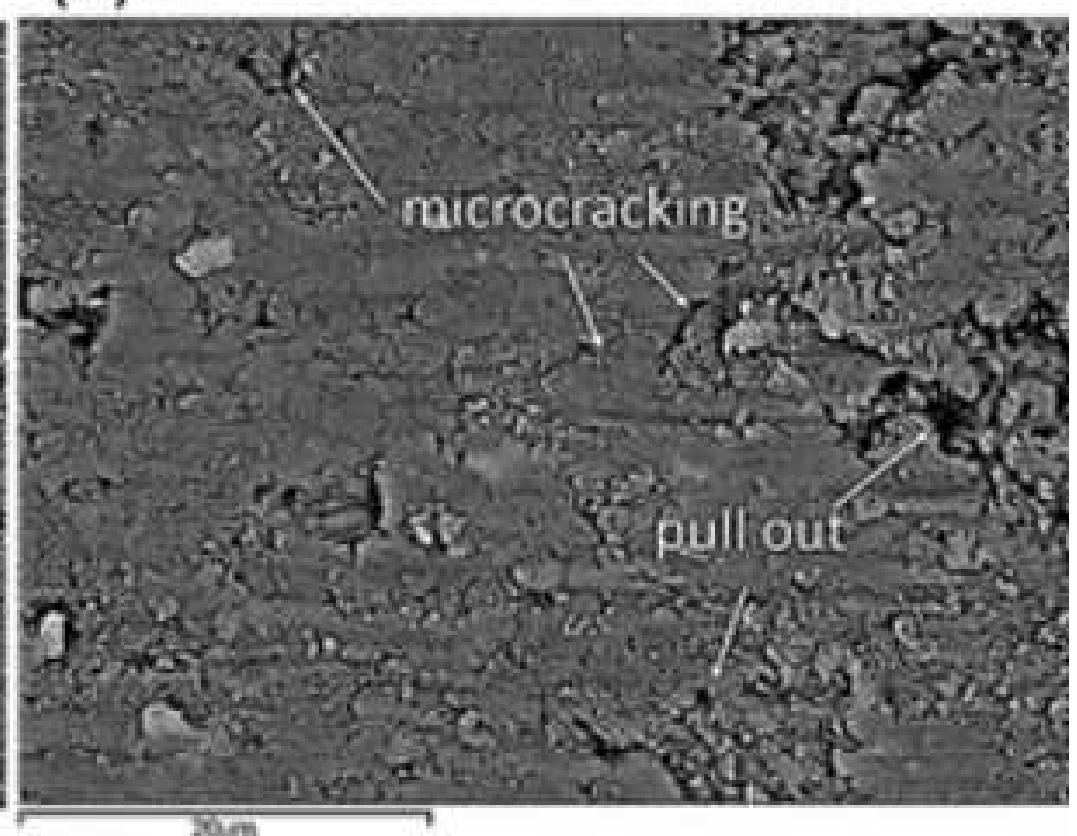

(d) 